\title{
Investigation of interaction between close and open types of SARS-Cov-2 spike glycoprotein with synthesized and natural Compounds as inhibitor; Molecular Docking Study
}

\section{Masume Jomhori}

Razi Vaccine \& Serum Research Institute, Mashhad, Iran

Hamid Mosaddeghi ( $\sim$ h.mosaddeghi@gmail.com )

Department of Chemistry, Payame Noor University, 19395-4697 Tehran, Iran

\section{Research Article}

Keywords: Coronavirus 2019, Spike glycoprotein, Molecular docking, Fluorophenyl, Propane.

Posted Date: July 7th, 2020

DOl: https://doi.org/10.21203/rs.3.rs-38089/v1

License: (c) (1) This work is licensed under a Creative Commons Attribution 4.0 International License. Read Full License 


\section{Abstract}

Purpose Viral diseases are increasingly endangering universal public health because of a shortage of successful antiviral therapies. The novel pandemic 2019 n-Cov2 disease (COVID-19) is recently identified as viral disorder triggered by a new type of coronavirus. This type of coronavirus binds to the host human receptors through the Spike glycoprotein(S) Receptor Binding Domain (RBD). Two types of spike protein have been identified in open and closed states in which the open type causes severe infection. Thus, this receptor is a significant target for antiviral drug design.

Methods Totally $111 * 2$ natural and synthetic compounds were chosen from the PubChem database as ligands. To recognize the ability of direct contact between ligands and the binding site of 2019 n-Cov 2 ACE2 protein, we have docked all compounds to the protein using AutoDock Vina. The FaF3-Drugs, Pan Assay Intrusion Compounds (PAINS), absorption, distribution, metabolism, excretion (ADME) and Lipinski's rules were used to evaluate the drug-like properties of the identified ligands. Antiviral compound prediction (AVC pred) also was used to assess antivirus properties.

Results The results showed that seven ligands out of all had interactions with spike protein-angiotensin converting enzyme 2 binding site. We have found that six out of seven ligands show drug-like characteristics. We also found that the fluorophenyl and propane groups of ligands had the best interaction with the binding site of the protein.

Conclusion Further, our results showed the ability of these ligands to prevent receptor binding of the spike protein SARS-CoV-2, so they would be considered as novel compounds of COVID-19 therapy drugs.

\section{Introduction}

Coronaviruses are the large family of viruses that belong to the family of coronaviridae. Based on genomic structures and phylogenetic relationships, the subfamily coronavirinae includes four sorts Alphacoronavirus, Betacoronavirus, Gammacoronavirus, and Deltacoronavirus (Woo et al. 2012). Recently named extreme acute respiratory syndrome coronavirus 2 (SARS-CoV-2), and categorized into the genus Betacoronavirus (Hui et al. 2020), that induce animal and human respiratory and intestinal infections (Vijay, Perlman 2016). Severe acute respiratory syndrome coronavirus (SARS-CoV), Middle East respiratory syndrome-related coronavirus(MERS-CoV), and Severe acute respiratory syndrome coronavirus2 (SARS-CoV-2) strains share the identity of the genome sequence nearly $79 \%$ and $50 \%$, respectively (Lu et al. 2020). However, significant contrasts as far as the study of disease transmission and physiopathology between these three infections have additionally been watched (Cruz et al. 2020; Huang et al. 2020; Wang et al. 2020). 2019-nCoV, classified as SARS-CoV-2, has a higher transmission risk than other in its family. SARS-CoV-2 is quite close to the other two widely studied coronaviruses; MERS-CoV and SARS-CoV (Organization 2020; Tai et al. 2020). However, there are still no antiviral medication and vaccine approved for the treatment and prevention of SARS-CoV-2 infections. Four important structure of coronaviruses are spikes $(S)$, envelopes $(E)$, membranes $(M)$, and nucleocapsid $(N)$ 
(Zhou et al. 2018; Cui et al. 2019). Angiotensin-converting enzyme 2(ACE2) is a key enzyme that SARSCoV and several SARS-related coronaviruses connect to it, in order to enter to target cells (Kirchdoerfer et al. 2018; Song et al. 2018). The most current findings suggest that the SARS-CoV-2 attaches to the ACE2 receptor on the host cell surface utilizing the spike protein receptor-binding domain (Goswami, Bagchi 2020; Walls et al. 2020; Li et al. 2005). The glycoprotein transmembrane spike which forms homo-trimer protruding from on the viral surface, helps coronaviruses to entrance into host cells (Walls et al. 2016). The spike glycoprotein on the coronavirus envelope synthesized nearly 1300 amino acids as a single precursor to the polypeptide chain and cleaved by host furin-like proteases into the amino (N)-terminal S1 subunit and the carboxyl (C)-terminal S2 subunit, the host cell connection, receptor binding and the stabilization of host cell membrane and viral membrane fusion during infection are four duties for which glycoprotein spikes are responsible (Du et al. 2009; Millet, Whittaker 2015). In Figures 1A, B, and 1C the homotrimer of SARS-CoV-2 S glycoproteins and a monomer protein respectively are represented. Two types of spike protein have been identified in open and closed states, that the closed SARS-CoV-2 S ectodomain trimer applying 3-fold symmetry with three ACE2-recognition motifs, whose location was meddled focuses on the crystal structure of SARS-CoV S in complex with ACE2(Figure1A) [16]. Opened SARS-CoV-2 $S$ is an asymmetric reconstruction of the trimmer with a single subunit B domain (Figure1B) [15]. On the whole, this information indicates that $S$ glycoprotein trimers present in profoundly pathogenic human coronaviruses seem to be in moderately opened states, although they remain mostly closed in common cold-related human coronaviruses (Guan et al. 2003; Li et al. 2004; Wan et al. 2020). Based on recent evidence the binding affinity of SARS-CoV for hACE2 with the rate of transmissibility, viral replication in distinct organisms, and seriousness of the disease is correlating [29,30], it is believed that the most pathogenic coronaviruses will indicate $S$ glycoprotein trimers spontaneously make closed and open conformations, as is the case with SARS-CoV-2, SARS-CoV and MERS-CoV, respectively (Walls et al. 2020). S1 and S2 subunits are Two functional subunits responsible for the host cell receptor, viral, and cell membrane combination that forms the spike glycoprotein (Belouzard et al. 2009; Bosch et al. 2003; Walls et al. 2016; Kirchdoerfer et al. 2016). The S1 subunits have two duties: this subunit comprises hl;ost cell attachment domains by identifying molecules of cell surface sugar and attaching to specific cellular receptors (Li 2015, 2016), Therefore, its receptor-binding domain (RBD) is critical in determining cell tropism, host range and zoonotic transmission of coronaviruses(Lu et al. 2015; Graham, Baric 2010). A hydrophobic fusion peptide and two heptad repeat regions compose the S2 subunit (Song et al. 2018). spike receptor-binding domain bound with the cell receptor ACE2 causes the triggers conformational changes in the S1 and S2 subunits, leading to the exposure of the fusion loop and its insertion into target cell membrane(Hofmann, Pöhlmann 2004; Lan et al. 2020). In this study, we have considered 6 different groups of ligands (Table 1): Anti-virus, Flavonoids, Fluorophenyls, Phenylpropanoids, some drugs that have been suggested for SARS-CoV-2, and compounds similar to fluorophenyl groups were virtually screened by Using the PubChem database that 3 compounds finally chosen which were Propane groups. Antiviruses have been used because of their antiviral properties and checking their effectiveness against SARS-CoV-2. Flavonoids are present in nearly all fruits and vegetables, as a category of natural substances with variable phenolic structures (Panche et al. 2016). These natural products are well known for their useful health effects such as antimicrobial activity, antioxidant, anticancer, and antivirus 
(Cushnie, Lamb 2005; Pietta 2000; Ren et al. 2003; Zhou, Li 2007). The compounds of fluorophenyl are composed of fluoro + phenyl, which are different compounds. As it is shown in the previous study, 2fluorophenyl, 3-fluorophenyl, and 4-fluorophenyl have antibiotic and antifungal activity so this compounds are used to docking in our study(Saleh et al. 2010). Phenylpropanoids are an enormous class of plant secondary metabolites got from aromatic amino acids phenylalanine in many plants or tyrosine in partial monocots. (Deng, Lu 2017). By having various biological functions, phenylpropanoids are useful for human health, so the systematic research has centered on natural and biotechnologically induced phenylpropanoids for medical usage as antioxidants, anticancer, antiviral, anti-inflammatory, wound healing, and antibacterial substances during the last few decades (Korkina et al. 2011). In this study, set of all six ligand groups will be investigated for interaction with the S1 subunit of SARS-CoV-2 spike glycoprotein by molecular docking. AutoDock vina (http://autodock.scripps.edu) is a popular opensource application for performing molecular docking, the prediction of ligand-receptor interactions. In the drug discovery process, molecular docking is a computationally intensive and prominent method. In this paper, we remember the criticality of research and the development of a COVID-19 drug by attaching ligands to the $S$ glycoprotein RDB, which could assume a compelling role in interfering with the spike refolding procedure and thus repressing viral entry into host cells.

\section{Methods}

\section{Protein preparation:}

As mentioned, the $\mathrm{S} 1$ subunit in the $\mathrm{B}$ domain is the main cause of the pathogenic difference of the SARS-CoV-2, so throughout this study, only the B chain was examined in both opened and closed types. The structure of the SARS-CoV-2 spike with closed and opened state (respectively with PDB ID: 6vxx and $6 \mathrm{vyb}$ ) was downloaded from Protein Data Bank (Berman et al. 2000). First, we used modeller 9.2 software for modeling the missing residue that located in subunit $\mathrm{S} 1$ for both B chains selected (after modeling the chains to obtain the amino acid number in the 6vxx (closed type) -87 and in the $6 \mathrm{vyb}$ (open type) -102 positional difference is the compared to downloaded structures from PDB) (Webb, Sali 2016; Fiser, Do 2000). The B chains and ligands were then translated to pdbqt format to dock in autodock vina software (Trott, Olson 2010). Before docking, polar hydrogens, and gasteiger charges were applied to the configuration of the $B$ chains and ligands. The autodock Vina docking tool was used to test ligand binding on the SARS-CoV-2 B chain. Additionally, blind docking of ligands was done to recognize the possible binding sites in the S1 subunit. For this, the entire protein was covered with the grid box of dimension $36.705070 .01 \AA$ for opened type protein and 63.2952 .1050 .14 for closed type with grid spacing $1 \AA$ A Finally the conformations with high negative binding energy in binding site that mentioned in the recent study are chosen(Walls et al. 2020; Lan et al. 2020; Yan et al. 2020).

\section{Ligands preparation}


ligands' 3-dimensional structure was extracted from the database of ChemSpider and PubChem, and these structures were then translated to PDB format by using the molecular visualization package of Chimera (Meng et al. 2006; Pettersen et al. 2004).

\section{Ligand receptor interaction analysis}

The docking results were analyzed using Ligplot+ and Discovery Studio Visualizer tool for a clear view of the best-docked complexes' receptor-ligand interaction (Laskowski, Swindells 2011; BIOVIA 2017; Studio 2008).

\section{Drug-like characteristic}

It is important to examine the main parameters associated with absorption, distribution, metabolism, excretion(ADME) properties such as the five rule of Lipinski, drug solubility, pharmacokinetic characteristic, molar refractivity, and drug likeliness in order to produce medicines with a good therapeutic index (Bueno 2020; Lipinski 2004). Development of drugs requires testing ADME progressively earlier in the discovery process, at a period when multiple compounds are regarded but access to physical samples is restricted, so computational prediction of the ADME identified ligands were predicted virtually (Daina et al. 2017). ADME profiling of all the ligands were determined using online software instrument (http://www.swissadme.ch). The original Lipinski R05 deals with orally active compounds and defines four simple ranges of physicochemical parameters ranging molecular weight (MWT) $\leq 500, \log \mathrm{P} \leq 5, \mathrm{H}-$ bond donors $\leq 10$, H-bond acceptors $\leq 10$ ) (Lipinski et al. 1997). Moreover, Pan Assay Intrusion Compounds(PAINS) identifies a variety of substructural features that may help recognize compounds that appear as frequent ligands (promiscuous compounds) in several high-throughput biochemical screens (Baell, Holloway 2010), FAF-Drugs3 filtering is used(Lagorce et al. 2015). Infections of SARS-CoV2 are actively threatening worldwide general health owing to a shortage of successful antiviral therapies, so in our work antiviral compound prediction (AVC pred) for chosen ligands was used (http://crdd.osdd.net/servers/avcpred/batch.php). In the AVCpred method, Experimental percentage inhibitory from ChEMBL, as a large-scale bioactivity database for drug discovery are used to foresees antiviral compounds against HIV, Hepatitis C virus (HCV), Hepatitis B virus (HBV), Human herpesvirus (HHV), and 26 other viruses (Qureshi et al. 2017).

\section{Results}

\section{Molecular docking}

Identify the ligands that bind to the $S_{B}$ domain-ACE2 binding site were conducted by molecular docking studies. 111 compounds which downloaded from the ChemSpider and PubChem databases, were subjected to molecular docking approaches. All ligands with their chemical formula, binding affinity in 
opened type, and $S^{B}$ domain residues interaction through hydrogen and hydrophobic bonds are shown in Table 1, that the amino acids in the2019 n-Cov 2 -ACE2 binding site are bolded in this table. (all this information for closed type is available as supplementary data file S1). According to molecular docking results, we selected seven identified ligands for drug-like filtering that have hydrogen and hydrophobic interacting in Spike 2019 n-cov2-ACE2 binding site in both closed and opened type that the amino acids in the2019 n-Cov 2 -ACE2 binding site are shown bolede in table 2. Rossicaside A has a hydrophobic binding with Tyr347 in the open state that is part of the binding area with $-7.4 \mathrm{Kcal} / \mathrm{mol}$ binding energy. 1,2-Ethanediol, 1,2-bis(4-fluorophenyl) with a binding energy of -6.6 Kcal $/ \mathrm{mol}$ in open type forming hydrogen bonds with Gly394 and three hydrophobic bindings that Tyr393 and Tyr403 are in S proteinACE2 binding site (Figure 2). 1,2-Propanediol, 3,3,3-trifluoro-2-phenyl-, (2R) with binding energy -6.7 $\mathrm{Kcal} / \mathrm{mol}$ forming a hydrogen bond with Gly394 and its hydrophobic bond were with Tyr393, Asn399, and Tyr403 residues (Figure 3). 1,1-bis(3-fluorophenyl)-2-methoxyethanol with a binding energy of $-6.6 \mathrm{Kcal} / \mathrm{mol}$ in open type forming hydrogen bonds with Gly394, GIn396, Asn399, Gly400 while other hydrophobic interacting residues were Tyr393 Tyr403(Figure 4). 1,1-diphenyl propane-1,2-diol also forming two hydrogen bonds with Gly394 and Asn399 and is also two hydrophobic bonds with Tyr393 and Tyr403(Figure 5). The seventh chosen ligand is (S)-1,1-Diphenylpropane-1,2-diol with $-6.2 \mathrm{Kcal} / \mathrm{mol}$ binding affinity that form hydrogen bonds with Gly394, Gln396 and Asn399 and hydrophobic bond with Tyr393 and Tyr403(Figure 6). In closed state hydrogen bonds and hydrophobic bond are mentioned in Table1(All hydrogen bonds in closed state showed as supplementary data file S2).

\section{Drug-like characteristic of the chosen ligands}

ADME is the guideline that essentially specifies the different molecular characteristic of a compound and is the prime prerequisite to be a possible drug-like (Matter et al. 2001). To assess the pharmacokinetic characteristic of the chosen ligands, we evaluated the Drug Likeliness for 7 chosen ligands based on Lipinski's rule of five (Lipinski et al. 1997). Lipinski 's rule of 5 suggests that weak absorption or permeation is more probable if more than $5 \mathrm{H}$-bond donors are involved, $10 \mathrm{H}$-bond acceptors, the molecular weight exceeds 500 Dalton, the calculated high lipophilicity (Log P) exceeds 5(Lipinski et al. 1997). The qualifying range for molar refractivity was between 40 and 130, with a mean value of 97(Matter et al. 2001). As in Table 3 is shown, just Rossicaside A cannot pass the Lipinski's rule of five, molar refractivity that is more than 130, and it is not a Drug Likeliness with 3 Violations. The remaining 6 chosen ligands passed all the parameters of the MADE (Table3). PAINS filtering to identify the existence of chemical groups belonging to the PAINS category. Six out of seven ligands were accepted as drug-like, and the physicochemical filter passed without any structural caution. The Rossicaside A is discarded which had the catechol group in the PAINS sub-structural moieties. Also, FAF-Drugs 3 filtering is rejected for Rossicaside A and other ligands are Accepted by this filtering. In continue we investigated antiviral properties of them. The result of prediction antiviral for chosen compounds are show in table 5 that show respectively Etrinavir, Rossicaside A, 1,1-bis(3-fluorophenyl)-2-methoxyethanol, 1,2-Ethanediol 1,2-bis(4fluorophenyl), 1,1-diphenylpropane-1,2-diol, (S)-1 1-Diphenylpropane-1 2-diol, 1,2-Propanediol, 3,3,3trifluoro-2-phenyl-(2R) with general rate $74.78,47.52,41.68,29.87,28.41,28.41,25.53$. A bar plot of the 
percentage of inhibition efficacy in each ligand for HBV, HCV, HHV, HIV, and General (26 viruses) is shown in Figure 7(A, B, C, D, and E). As is clear in figure 7D, final ligands have the most percentage inhibition efficacy on the HIV virus with average efficacy $\% 65 / 55$. The minimum percentage of inhibition efficacy is shown in figure 7C which shows the HHV with average $\% 16 / 81$.

\section{Discussion}

In the specialized field of computer-aided drug designing to discover a new compound, molecular docking is widely used to explore the different forms of the binding interaction between the prospective drug and the various domains or active sites, and binding sites on the target molecules (Raj et al. 2019; Hughes et al. 2011). It's been years that molecular docking is a great tool for the exploration of medicines. This is used to model atomic level binding between proteins and small molecules, which helps us to characterize the actions of small molecules at the target protein binding site (Meng et al. 2011). In viral infections due to the lack of successful antiviral therapies, there is an urgency to speed up the process of drug development to find new and effective drug candidates. Attachment, fusion, and entry into the host cells are 3 duties that glycoprotein of the 2019 novel coronavirus plays important roles in these works that it is a SARS-CoV-2S surface protein(Yan et al. 2020). B chain in this protein is a factor that causes the formation of two open and closed forms of coronavirus that in terms of structural biology is in a heterotrimeric form with three different polypeptide chains: chain $A$, chain $B$, and chain $C$ making each monomer (Walls et al. 2020). In this work, the B chain of spike glycoprotein CoV2 in 2 forms closed and opened (PDB ID: 6vyb and 6vxx) were modeled for modeling the missing residue and molecular docking done with about 111 combinations were screened from the ChemSpider and PubChem databases (Table 1) to find the best ligand to block the B-chain binding site connection with ACE2. The compound ID(CID) of selected ligands from PubChem are: CID 13916145, CID 193962, CID 2755890, CID 11095754, CID 53722331, CID 555451, CID 736300, which showed have interaction with Spike 2019 n-cov2-ACE2 binding site residues with the energy of binding affinity, respectively: $-7.5 \mathrm{Kcal} / \mathrm{mol},-7.4 \mathrm{Kcal} / \mathrm{mol}$, $-6.7 \mathrm{Kcal} / \mathrm{mol},-6.7 \mathrm{Kcal} / \mathrm{mol},-6.6 \mathrm{Kcal} / \mathrm{mol},-6.4 \mathrm{Kcal} / \mathrm{mol},-6.2 \mathrm{Kcal} / \mathrm{mol}$. Among all different types of interactions such as $\mathrm{H}$-bond, $\pi-\pi$, amide- $\pi$ interactions, etc that always analyzed, ligand efficacy refers to the ability to bind the target's binding sites has commonly set out analyzing its hydrogen-bonding pattern and the properties of residues engaged at the binding site (Raj et al. 2019; Hughes et al. 2011). 7 final ligands are: Rossicaside $A$ is a phenylpropanoid, which phenylpropanoids and their derivatives are commonly found in fruits, vegetables, grains of cereals, beverages, spices, and herbs. It is considered that antimicrobial, antioxidant, anti-inflammatory, antidiabetic, anticancer action, and show renoprotective, neuroprotective, cardioprotective, and hepatoprotective effects are multifaceted effects of phenylpropanoids (Jia et al. 2018; Shyr et al. 2006). Rossicaside A is an antioxidant that is used in this sudy (Gálvez et al. 2006). Etravirine is a reverse transcriptase inhibitor of the next-generation, nonnucleoside, that administered orally and it is endorsed for the treatment of Infection of HIV-1 in experienced grown-up patients who have proof viral replication and are harboring HIV-1 strains resistant to other antiretrovirals (ARV) agents (Croxtall 2012). There are different combinations of this structure, 1,2-Ethanediol, 1,2-bis(4-fluorophenyl) and 1,1-bis(3-fluorophenyl)-2-methoxyethanol are 2 fluorophenyl 
compounds that in our study formed hydrogen and hydrophobic interactions in S protein-ACE2 binding area so we also use three ligands (1,2-Propanediol, 3,3,3-trifluoro-2-phenyl-, (2R), 1,1-diphenyl propane-1,2diol and (S)-1,1-Diphenylpropane-1,2-diol) that had closed structure to fluorophenyl compounds. As in drug-like characteristics of the chosen ligands analysis shown, we conclude that most of the important pharmacophoric characteristics required for an adequate restraint of the $S_{B}$ protein are accepted by six ligands recognized from the PubChem database. Moreover, their binding with chain B in both type forms a stable complex with a sturdy network of hydrogen, hydrophobic bonds and important residues, namely: Tyr347,as Phe377, Tyr393,Gly394, Gln396, Asn399, Gly400, Tyr403, Tyr408, Gly409, Gln411, Asn414 that were recently predicted as close contact residues with the human cell host receptor (Shang et al. 2020; Walls et al. 2020). Using the ADMEtox filtering, all ligands identified were assessed for pharmacokinetic properties. The rule of five Lipinski theory is commonly used to determine possible reactions between medication and other non-drug target molecules. In Lipinski's rule, it is mentioned that for any compound to be chosen as a potential drug it ought to have (a) Molecular mass $<500$ Dalton (b) high lipophilicity (expressed as LogP<5) (c) less than 5 hydrogen bond donors (d) Less than 10 hydrogen bond acceptors (e), also molar refractivity between 40-130 and drug Likeliness are 2 another factor that investigated in ADMEtox filtering. In the event that a compound has more than two of the previously mentioned measures, then the compound is probably going to be a potential drug candidate (Table 3 ). Also PAINS and FAF-Drugs 3 filtering are 2 other drugs-filtering that FAF-Drugs 3 is a program for filtering large compound libraries in silico screening experiments or related modeling studies and PAINS filtering can process hundreds and thousands of compounds in seconds and are in widespread current use to identify PAINS in order to exclude them from further analysis. In table 4 it is shown that in 7 final ligands just Rossicaside A is rejected also by these filtering and others are accepted. Antiviral compound prediction is the final analysis that in this study investigated for chosen ligands, which AVCpred is an instrument to accelerate the drug discovery procedure to recognize novel and efficacious antivirus drug candidates (Table 5, Figure 7). The ligands chosen have the most percent inhibition of HIV efficacy as shown in Figure 7D, and in the other groups of viruses, they have the antiviral properties that show that final ligands can be used as antivirus drugs. Thus we suggest that all of these ligands except Rossicaside $A$ have the potential ability to be an effective drug. In this work we used molecular docking to reveal whether there was any close interaction with 2019 n-cov2 ligands and $S_{B}$ proteins, the result showed acceptable binding of Etravirine, 1,2-Ethanediol, 1,2-bis(4-fluorophenyl), 1,2-Propanediol, 3,3,3-trifluoro-2phenyl-(2R), 1,1-bis(3-fluorophenyl)-2-methoxy ethanol, 1,1-diphenyl propane-1,2-diol and (S)-1,1Diphenylpropane-1,2-diol of calcitriol with some amino acids of the binding site of $B$ chain of spike protein through hydrogen and hydrophobic interactions bonds. It is noteworthy that in this study we decided to share our discoveries with all the researchers who work for experimental drug verification in the area of anti-SARS-CoV-2 research over the world.

\section{Conclusion}

The main objective of the present study was to find the best ligand by molecular docking and evaluation of binding interaction against the B chain SARS-CoV-2 with ACE2. Seven compounds from the PubChem 
database were chosen based on interaction against the binding site of the B chain SARS-CoV-2-ACE2. Six final ligands were selected according to drug-like characteristic (CID 193962, CID 2755890, CID 11095754, CID 53722331, CID 555451, CID 736300). These results show that these compounds could potentially be used as a drug against SARS-CoV-2.

\section{Declarations}

Acknowledgments The authors are thankful for helpful feedback and observations to the reviewers and editors, which helped enhance the paper quality. The authors do not have any relevant affiliations or financial involvement with any organization or entity having a financial interest.

\section{Compliance with ethical standards}

Conflict of interest The authors declare that there are no conflicts of interest.

Ethical approval This article does not contain any studies with human participants and animals performed by any of the authors.

\section{References}

Baell JB, Holloway GA. New substructure filters for removal of pan assay interference compounds (PAINS) from screening libraries and for their exclusion in bioassays. Journal of medicinal chemistry. 2010;53(7):2719-40.

Belouzard S, Chu VC, Whittaker GR. Activation of the SARS coronavirus spike protein via sequential proteolytic cleavage at two distinct sites. Proceedings of the National Academy of Sciences. 2009;106(14):5871-6.

Berman HM, Westbrook J, Feng Z, Gilliland G, Bhat TN, Weissig H et al. The Protein Data Bank. Nucleic Acids Research. 2000;28(1):235-42. doi:10.1093/nar/28.1.235.

BIOVIA DS. Discovery studio visualizer. San Diego, CA, USA. 2017.

Bosch BJ, van der Zee R, de Haan CA, Rottier PJ. The coronavirus spike protein is a class I virus fusion protein: structural and functional characterization of the fusion core complex. Journal of virology. 2003;77(16):8801-11.

Bueno J. ADMETox: Bringing Nanotechnology Closer to Lipinski's Rule of Five. Preclinical Evaluation of Antimicrobial Nanodrugs. Springer; 2020. p. 61-74.

Croxtall JD. Etravirine. Drugs. 2012;72(6):847-69.

Cruz MVCP, Estepa-Garcia K, Bautista LMH, Lardizabal-Bunyi JE, Joves Jr PB, Abrogena MLAB et al. Family-focused Home Care Plan During a COVID-19 Epidemic: A Consensus Statement by the PAFP Task 
Force on COVID-19. 2020.

Cui J, Li F, Shi Z-L. Origin and evolution of pathogenic coronaviruses. Nature reviews Microbiology. 2019;17(3):181-92.

Cushnie TT, Lamb AJ. Antimicrobial activity of flavonoids. International journal of antimicrobial agents. 2005;26(5):343-56.

Daina A, Michielin O, Zoete V. SwissADME: a free web tool to evaluate pharmacokinetics, drug-likeness and medicinal chemistry friendliness of small molecules. Scientific reports. 2017;7:42717.

Deng Y, Lu S. Biosynthesis and regulation of phenylpropanoids in plants. Critical Reviews in Plant Sciences. 2017;36(4):257-90.

Du L, He Y, Zhou Y, Liu S, Zheng B-J, Jiang S. The spike protein of SARS-CoV-a target for vaccine and therapeutic development. Nature Reviews Microbiology. 2009;7(3):226-36.

Fiser A, Do RKG. Modeling of loops in protein structures. Protein science. 2000;9(9):1753-73.

Gálvez M, Martín-Cordero C, Ayuso MJ. Pharmacological activities of phenylpropanoids glycosides. Studies in Natural Products Chemistry. Elsevier; 2006. p. 675-718.

Goswami T, Bagchi B. Molecular Docking study of Receptor Binding Domain of SARS-CoV-2 Spike Glycoprotein with Saikosaponin, a Triterpenoid Natural Product. 2020.

Graham RL, Baric RS. Recombination, reservoirs, and the modular spike: mechanisms of coronavirus cross-species transmission. Journal of virology. 2010;84(7):3134-46.

Guan Y, Zheng B, He Y, Liu X, Zhuang Z, Cheung C et al. Isolation and characterization of viruses related to the SARS coronavirus from animals in southern China. Science. 2003;302(5643):276-8.

Hofmann H, Pöhlmann S. Cellular entry of the SARS coronavirus. Trends in microbiology. 2004;12(10):466-72.

Huang C, Wang Y, Li X, Ren L, Zhao J, Hu Y et al. Clinical features of patients infected with 2019 novel coronavirus in Wuhan, China. The Lancet. 2020;395(10223):497-506.

Hughes JP, Rees S, Kalindjian SB, Philpott KL. Principles of early drug discovery. British journal of pharmacology. 2011;162(6):1239-49.

Hui DS, I Azhar E, Madani TA, Ntoumi F, Kock R, Dar O et al. The continuing 2019-nCoV epidemic threat of novel coronaviruses to global health-The latest 2019 novel coronavirus outbreak in Wuhan, China. International Journal of Infectious Diseases. 2020;91:264-6. 
Jia Y, He Y, Lu F. The structure-antioxidant activity relationship of dehydrodiferulates. Food chemistry. 2018;269:480-5.

Kirchdoerfer RN, Cottrell CA, Wang N, Pallesen J, Yassine HM, Turner HL et al. Pre-fusion structure of a human coronavirus spike protein. Nature. 2016;531(7592):118-21.

Kirchdoerfer RN, Wang N, Pallesen J, Wrapp D, Turner HL, Cottrell CA et al. Stabilized coronavirus spikes are resistant to conformational changes induced by receptor recognition or proteolysis. Scientific reports. 2018;8(1):1-11.

Korkina L, Kostyuk V, De Luca C, Pastore S. Plant phenylpropanoids as emerging anti-inflammatory agents. Mini reviews in medicinal chemistry. 2011;11(10):823-35.

Lagorce D, Sperandio O, Baell JB, Miteva MA, Villoutreix BO. FAF-Drugs3: a web server for compound property calculation and chemical library design. Nucleic acids research. 2015;43(W1):W200-W7.

Lan J, Ge J, Yu J, Shan S, Zhou H, Fan S et al. Crystal structure of the 2019-nCoV spike receptor-binding domain bound with the ACE2 receptor. bioRxiv. 2020.

Laskowski RA, Swindells MB. LigPlot+: multiple ligand-protein interaction diagrams for drug discovery. ACS Publications; 2011.

Li F. Receptor recognition mechanisms of coronaviruses: a decade of structural studies. Journal of virology. 2015;89(4):1954-64.

Li F. Structure, function, and evolution of coronavirus spike proteins. Annual review of virology. 2016;3:237-61.

Li F, Li W, Farzan M, Harrison SC. Structure of SARS coronavirus spike receptor-binding domain complexed with receptor. Science. 2005;309(5742):1864-8.

Li W, Greenough TC, Moore MJ, Vasilieva N, Somasundaran M, Sullivan JL et al. Efficient replication of severe acute respiratory syndrome coronavirus in mouse cells is limited by murine angiotensin-converting enzyme 2. Journal of virology. 2004;78(20):11429-33.

Lipinski CA. Lead-and drug-like compounds: the rule-of-five revolution. Drug Discovery Today: Technologies. 2004;1(4):337-41.

Lipinski CA, Lombardo F, Dominy BW, Feeney PJ. Experimental and computational approaches to estimate solubility and permeability in drug discovery and development settings. Advanced drug delivery reviews. 1997;23(1-3):3-25.

Lu G, Wang Q, Gao GF. Bat-to-human: spike features determining 'host jump'of coronaviruses SARS-CoV, MERS-CoV, and beyond. Trends in microbiology. 2015;23(8):468-78. 
Lu R, Zhao X, Li J, Niu P, Yang B, Wu H et al. Genomic characterisation and epidemiology of 2019 novel coronavirus: implications for virus origins and receptor binding. The Lancet. 2020;395(10224):565-74.

Matter H, Barighaus K, Naumann T, Klabunde T, Pirard B. Computational approaches towards the rational design of drug-like compound libraries. Combinatorial chemistry \& high throughput screening. 2001;4(6):453-75.

Meng EC, Pettersen EF, Couch GS, Huang CC, Ferrin TE. Tools for integrated sequence-structure analysis with UCSF Chimera. BMC bioinformatics. 2006;7(1):339.

Meng X, Zhang H, Mezei M, Cui M. Molecular docking: a powerful approach for structure-based drug discovery. Curr Comp Aided Drug Des 7 (2): 146-157. 2011.

Millet JK, Whittaker GR. Host cell proteases: Critical determinants of coronavirus tropism and pathogenesis. Virus research. 2015;202:120-34.

Organization WH. Coronavirus disease 2019 (COVID-19): situation report, 59. 2020.

Panche A, Diwan A, Chandra S. Flavonoids: an overview. Journal of nutritional science. 2016;5.

Pettersen EF, Goddard TD, Huang CC, Couch GS, Greenblatt DM, Meng EC et al. UCSF Chimera-a visualization system for exploratory research and analysis. Journal of computational chemistry. 2004;25(13):1605-12.

Pietta P-G. Flavonoids as antioxidants. Journal of natural products. 2000;63(7):1035-42.

Qureshi A, Kaur G, Kumar M. AVC pred: an integrated web server for prediction and design of antiviral compounds. Chemical biology \& drug design. 2017;89(1):74-83.

Raj S, Sasidharan S, Dubey VK, Saudagar P. Identification of lead molecules against potential drug target protein MAPK4 from L. donovani: An in-silico approach using docking, molecular dynamics and binding free energy calculation. PloS one. 2019;14(8).

Ren W, Qiao Z, Wang H, Zhu L, Zhang L. Flavonoids: promising anticancer agents. Medicinal research reviews. 2003;23(4):519-34.

Saleh M, Abbott S, Perron V, Lauzon C, Penney C, Zacharie B. Synthesis and antimicrobial activity of 2fluorophenyl-4, 6-disubstituted [1,3,5] triazines. Bioorganic \& medicinal chemistry letters. 2010;20(3):9459.

Shang J, Ye G, Shi K, Wan Y, Luo C, Aihara H et al. Structural basis of receptor recognition by SARS-CoV-2. Nature. 2020:1-8.

Shyr M-H, Tsai T-H, Lin L-C. Rossicasins A, B and rosicaside F, three new phenylpropanoid glycosides from Boschniakia rossica. Chemical and pharmaceutical bulletin. 2006;54(2):252-4. 
Song W, Gui M, Wang X, Xiang Y. Cryo-EM structure of the SARS coronavirus spike glycoprotein in complex with its host cell receptor ACE2. PLoS pathogens. 2018;14(8):e1007236.

Studio D. Discovery Studio. Accelrys [21]. 2008.

Tai W, He L, Zhang X, Pu J, Voronin D, Jiang S et al. Characterization of the receptor-binding domain (RBD) of 2019 novel coronavirus: implication for development of RBD protein as a viral attachment inhibitor and vaccine. Cellular \& Molecular Immunology. 2020:1-8.

Trott O, Olson AJ. AutoDock Vina: improving the speed and accuracy of docking with a new scoring function, efficient optimization, and multithreading. Journal of computational chemistry. 2010;31(2):45561.

Vijay R, Perlman S. Middle East respiratory syndrome and severe acute respiratory syndrome. Current opinion in virology. 2016;16:70-6.

Walls AC, Park Y-J, Tortorici MA, Wall A, McGuire AT, Veesler D. Structure, function, and antigenicity of the SARS-CoV-2 spike glycoprotein. Cell. 2020.

Walls AC, Tortorici MA, Frenz B, Snijder J, Li W, Rey FA et al. Glycan shield and epitope masking of a coronavirus spike protein observed by cryo-electron microscopy. Nature structural \& molecular biology. 2016;23(10):899.

Wan Y, Shang J, Graham R, Baric RS, Li F. Receptor recognition by the novel coronavirus from Wuhan: an analysis based on decade-long structural studies of SARS coronavirus. Journal of virology. 2020;94(7).

Wang Y, Wang Y, Chen Y, Qin Q. Unique epidemiological and clinical features of the emerging 2019 novel coronavirus pneumonia (COVID-19) implicate special control measures. Journal of medical virology. 2020.

Webb B, Sali A. Comparative protein structure modeling using MODELLER. Current protocols in bioinformatics. 2016;54(1):5.6. 1-5.6. 37.

Woo PC, Lau SK, Lam CS, Lau CC, Tsang AK, Lau JH et al. Discovery of seven novel Mammalian and avian coronaviruses in the genus deltacoronavirus supports bat coronaviruses as the gene source of alphacoronavirus and betacoronavirus and avian coronaviruses as the gene source of gammacoronavirus and deltacoronavirus. Journal of virology. 2012;86(7):3995-4008.

Yan R, Zhang Y, Li Y, Xia L, Guo Y, Zhou Q. Structural basis for the recognition of SARS-CoV-2 by fulllength human ACE2. Science. 2020;367(6485):1444-8.

Zhou X, Li H-j. Bioactivities and clinical applications of flavonoids. CHINESE NEW DRUGS JOURNAL. 2007;16(5):350. 
Zhou Y, Jiang S, Du L. Prospects for a MERS-CoV spike vaccine. Expert review of vaccines. 2018;17(8):677-86.

\section{Tables}

Table 1 Result of 6vyb molecular docking with all ligands, which are under study in this work. 5 ligand groups are ranked by binding affinity. 


\begin{tabular}{|c|c|c|c|c|}
\hline Ligand name & $\begin{array}{l}\text { Chemical } \\
\text { formula }\end{array}$ & $\begin{array}{c}\text { Binding } \\
\text { Affinity } \\
(\mathrm{Kcal} / \mathrm{mol})\end{array}$ & $\begin{array}{l}\text { Residues interaction with } \\
\text { Ligand through hydrogen } \\
\text { binding }\end{array}$ & $\begin{array}{l}\text { Residues interaction with Ligand } \\
\text { through Hydrophobic binding }\end{array}$ \\
\hline \multicolumn{5}{|c|}{ Anti-viruses } \\
\hline Indinavir & $\mathrm{C}_{36} \mathrm{H}_{47} \mathrm{~N}_{5} \mathrm{O}_{4}$ & -8.1 & Asn241, Asn335 & Phe240, Phe272, Leu339 \\
\hline Maraviroc & $\mathrm{C}_{29} \mathrm{H}_{41} \mathrm{~F}_{2} \mathrm{~N}_{5} \mathrm{O}$ & -8 & G424 & $\begin{array}{l}\text { Phe227, Ile230, Thr231, Asp287, } \\
\text { Lys426 }\end{array}$ \\
\hline Raltegravir & $\mathrm{C}_{20} \mathrm{H}_{21} \mathrm{FN}_{6} \mathrm{O}_{5}$ & -8 & Ser269, Trp334, Arg407 & Val265 \\
\hline Saquinavir & $\mathrm{C}_{38} \mathrm{H}_{50} \mathrm{~N}_{6} \mathrm{O}_{5}$ & -7.7 & Ser264, Pro425 & Val225, Ile230, Lys427 \\
\hline Methylprednisolone & $\mathrm{C}_{22} \mathrm{H}_{30} \mathrm{O}_{5}$ & -7.6 & Arg253, Thr328, Gln414 & Phe362 \\
\hline Etravirine & $\mathrm{C}_{20} \mathrm{H}_{15} \mathrm{BrN}_{6} \mathrm{O}$ & -7.5 & Ser271 & $\begin{array}{c}\text { Phe240, Asn241, Phe272, Trp334, } \\
\text { Leu339 }\end{array}$ \\
\hline Acteoside & $\mathrm{C}_{29} \mathrm{H}_{36} \mathrm{O}_{1}$ & -7.3 & $\begin{array}{l}\text { Phe240, Asn241, Asn335, } \\
\text { Asn338, Gln404 }\end{array}$ & Phe272, Trp334 \\
\hline Cyclosporin A & $\mathrm{C}_{62} \mathrm{H}_{111} \mathrm{~N}_{11} \mathrm{O}_{12}$ & -7.2 & $\operatorname{Arg} 253$ & $\begin{array}{c}\text { Phe290, Tyr294, Phe327, Thr328, } \\
\text { Phe362, Leu415, Leu416 }\end{array}$ \\
\hline Nelfinavir & $\mathrm{C}_{32} \mathrm{H}_{45} \mathrm{~N}_{3} \mathrm{O}_{4} \mathrm{~S}$ & -7.1 & Thr421, Cys423 & $\begin{array}{l}\text { Phe227, Pro228, Ile230, Thr231, } \\
\text { Val260, Lys426 }\end{array}$ \\
\hline Efavirenz & $\mathrm{C}_{14} \mathrm{H}_{9} \mathrm{ClF}_{3} \mathrm{NO}_{2}$ & -7 & Thr328 & Tyr294, Pro324, Phe362 \\
\hline Aldosterone & $\mathrm{C}_{21} \mathrm{H}_{28} \mathrm{O}_{5}$ & -6.9 & Arg253, Thr328, Glu414 & Phe362 \\
\hline Delavirdine & $\mathrm{C}_{22} \mathrm{H}_{28} \mathrm{~N}_{6} \mathrm{O}_{3} \mathrm{~S}$ & -6.9 & Asn258 & Phe227, Asn258 \\
\hline Alclometasone & $\mathrm{C}_{22} \mathrm{H}_{29} \mathrm{ClO}_{5}$ & -6.8 & Thr328, Pro361, Phe362 & Phe362, Glu414 \\
\hline Abacavir & $\mathrm{C}_{14} \mathrm{H}_{18} \mathrm{~N}_{6} \mathrm{O}$ & -6.7 & Ser269. Ser271 & Val265, Leu266, Phe272 \\
\hline Atazanavir & $\mathrm{C}_{38} \mathrm{H}_{52} \mathrm{~N}_{6} \mathrm{O}_{7}$ & -6.6 & $\operatorname{Arg} 253$ & $\begin{array}{l}\text { Phe290, Tyr294, Phe328, Phe362, } \\
\text { Leu415, Leu416 }\end{array}$ \\
\hline Imiquimod & $\mathrm{C}_{14} \mathrm{H}_{16} \mathrm{~N}_{4}$ & -6.6 & - & Leu266, Phe272, Trp334 \\
\hline Lopinavir & $\mathrm{C}_{37} \mathrm{H}_{48} \mathrm{~N}_{4} \mathrm{O}_{5}$ & -6.6 & Cys259 & $\begin{array}{c}\text { Phe227, Pro228, Ile230, Thr231, } \\
\text { Asn258, Val260, Lys426 }\end{array}$ \\
\hline Entecavir & $\mathrm{C}_{12} \mathrm{H}_{15} \mathrm{~N}_{5} \mathrm{O}_{3}$ & -6.5 & Cys259 & - \\
\hline Sofosbuvir & $\mathrm{C}_{22} \mathrm{H}_{29} \mathrm{FN}_{3} \mathrm{O}_{9} \mathrm{P}$ & -6.5 & Cys259, Asn442 & $\begin{array}{l}\text { Phe227, Pro228, Ile230, Asn258, } \\
\text { Thr421, Lys426 }\end{array}$ \\
\hline Zidovudine & $\mathrm{C}_{10} \mathrm{H}_{13} \mathrm{~N}_{5} \mathrm{O}_{4}$ & -6.4 & Ala420, Gly424 & - \\
\hline Stavudine & $\mathrm{C}_{10} \mathrm{H}_{12} \mathrm{~N}_{2} \mathrm{O}_{4}$ & -6.3 & Ser269, Ser271 & Phe240, Phe272, Phe272, Leu339 \\
\hline Telbivudine & $\mathrm{C}_{10} \mathrm{H}_{14} \mathrm{~N}_{2} \mathrm{O}_{5}$ & -6.3 & Ser271, Arg 407 & Phe240, Phe272, Trp334, Leu339 \\
\hline Zalcitabine & $\mathrm{C}_{9} \mathrm{H}_{13} \mathrm{~N}_{3} \mathrm{O}_{3}$ & -6.3 & Ser271 & Phe240, Leu266, Trp334 \\
\hline Didanosine & $\mathrm{C}_{10} \mathrm{H}_{12} \mathrm{~N}_{4} \mathrm{O}_{3}$ & -6.1 & $\begin{array}{c}\text { Phe240, Asn241, Ser269, } \\
\text { Ser271 }\end{array}$ & Phe272 \\
\hline Nevirapine & $\mathrm{C}_{15} \mathrm{H}_{14} \mathrm{~N}_{4} \mathrm{O}$ & -6.1 & - & Phe240, Phe272, Trp334 \\
\hline Ribavirin & $\mathrm{C}_{8} \mathrm{H}_{12} \mathrm{~N}_{4} \mathrm{O}_{5}$ & -6.1 & $\begin{array}{c}\operatorname{Arg} 352, \operatorname{Arg} 355, \text { Ser367, } \\
\text { Gln369 }\end{array}$ & - \\
\hline Telaprevir & $\mathrm{C}_{36} \mathrm{H}_{53} \mathrm{~N}_{7} \mathrm{O}_{6}$ & -6.1 & - & $\begin{array}{l}\text { Phe227, Pro228, Ile230, Val260, } \\
\text { Lys426, Asn442 }\end{array}$ \\
\hline Emtricitabine & $\mathrm{C}_{8} \mathrm{H}_{10} \mathrm{FN}_{3} \mathrm{O}_{3} \mathrm{~S}$ & -6 & $\begin{array}{l}\text { Cys259, Thr421, Gly424, } \\
\text { Lys426 }\end{array}$ & - \\
\hline Ganciclovir & $\mathrm{C}_{9} \mathrm{H}_{13} \mathrm{~N}_{5} \mathrm{O}_{4}$ & -5.9 & Phe240, Trp334, Arg407 & Ala242, Ser269, Ser271, Arg407 \\
\hline Fosamprenavir & $\mathrm{C}_{25} \mathrm{H}_{36} \mathrm{~N}_{3} \mathrm{O}_{9} \mathrm{PS}$ & -5.8 & Thr231 & Phe227, Pro228, Val260,Lys426 \\
\hline Penciclovir & $\mathrm{C}_{10} \mathrm{H}_{15} \mathrm{~N}_{5} \mathrm{O}_{3}$ & -5.8 & $\begin{array}{l}\text { Phe227, Pro228, Asp262, } \\
\text { Lys } 426\end{array}$ & Ile230, Pro425, Lys427 \\
\hline
\end{tabular}




\begin{tabular}{|c|c|c|c|c|}
\hline Rimantadine & $\mathrm{C}_{12} \mathrm{H}_{21} \mathrm{~N}$ & -5.8 & Cys234, Gly237 & Leu233, Phe236, Val265, Leu266 \\
\hline Lamivudine & $\mathrm{C}_{8} \mathrm{H}_{11} \mathrm{~N}_{3} \mathrm{O}_{3} \mathrm{~S}$ & -5.7 & $\begin{array}{c}\text { Pro228, Cys259, Thr421, } \\
\text { Gly424, Lys426 }\end{array}$ & Thr231 \\
\hline Valganciclovir & $\mathrm{C}_{14} \mathrm{H}_{22} \mathrm{~N}_{6} \mathrm{O}_{5}$ & -5.7 & - & Phe240, Ser269, Ser271 \\
\hline Aciclovir & $\mathrm{C}_{8} \mathrm{H}_{11} \mathrm{~N}_{5} \mathrm{O}_{3}$ & -5.6 & $\begin{array}{c}\text { Phe240, Asn241, Ser269, } \\
\text { Ser271 }\end{array}$ & - \\
\hline Gancyclovir & $\mathrm{C}_{9} \mathrm{H}_{13} \mathrm{~N}_{5} \mathrm{O}_{4}$ & -5.6 & Phe240, Asn241 & - \\
\hline Ritonavir & $\mathrm{C}_{37} \mathrm{H}_{48} \mathrm{~N}_{6} \mathrm{O}_{5} \mathrm{~S}_{2}$ & -5.6 & - & Pro228, Thr231, Val260, Asn442 \\
\hline Tenofovir & $\mathrm{C}_{9} \mathrm{H}_{14} \mathrm{~N}_{5} \mathrm{O}_{4} \mathrm{P}$ & -5.6 & Trp334 & Phe272, Trp334 \\
\hline Valaciclovir & $\mathrm{C}_{13} \mathrm{H}_{20} \mathrm{~N}_{6} \mathrm{O}_{4}$ & -5.6 & Asn241, Ser269, Trp334 & Leu339 \\
\hline Famciclovir & $\mathrm{C}_{14} \mathrm{H}_{19} \mathrm{~N}_{5} \mathrm{O}_{4}$ & -5.5 & Ala420 & Phe227, Ile230, Thr231, Val260 \\
\hline Idoxuridine & $\mathrm{C}_{9} \mathrm{H}_{11} \mathrm{IN}_{2} \mathrm{O}_{5}$ & -5.5 & $\operatorname{Trp334}$ & - \\
\hline Oseltamivir & $\mathrm{C}_{16} \mathrm{H}_{28} \mathrm{~N}_{2} \mathrm{O}_{4}$ & -5.5 & Asp318, Thr328, Ser412 & Pro324, Thr328, Phe362, Glu414 \\
\hline Zanamivir & $\mathrm{C}_{12} \mathrm{H}_{20} \mathrm{~N}_{4} \mathrm{O}_{7}$ & -5.5 & Arg226, Ser428, Gln478 & - \\
\hline Amantadine & $\mathrm{C}_{10} \mathrm{H}_{17} \mathrm{~N}$ & -5.3 & Pro228, Asn229 & Val260, Lys426 \\
\hline Docosanol & $\mathrm{C}_{22} \mathrm{H}_{46} \mathrm{O}$ & -3.8 & - & $\begin{array}{l}\text { Ile230, Leu233, Phe236, Val265, } \\
\text { Leu266, Pro425 }\end{array}$ \\
\hline Methoxyethanol & $\mathrm{C}_{3} \mathrm{H}_{8} \mathrm{O}_{2}$ & 2.9 & $\begin{array}{c}\text { Arg352, Lys356, Ser367, } \\
\text { Glu369 }\end{array}$ & - \\
\hline Enfuvirtide & $\mathrm{C}_{204} \mathrm{H}_{301} \mathrm{~N}_{51} \mathrm{O}_{64}$ & -2.2 & Ser257 & - \\
\hline \multicolumn{5}{|c|}{ Drug of cov2 } \\
\hline Baloxavir marboxil & $\mathrm{C}_{27} \mathrm{H}_{23} \mathrm{~F}_{2} \mathrm{~N}_{3} \mathrm{O}_{7} \mathrm{~S}$ & -7.7 & - & $\begin{array}{l}\text { Phe227, Pro228, Ile230, Thr231, } \\
\text { Lys426, Asn442 }\end{array}$ \\
\hline Indomethacin & $\mathrm{C}_{19} \mathrm{H}_{16} \mathrm{ClNO}_{4}$ & -7 & Pro228 & Ile230, Thr231, Val260, Lys426 \\
\hline Azvudine & $\mathrm{C}_{9} \mathrm{H}_{11} \mathrm{FN}_{6} \mathrm{O}_{4}$ & -6.2 & Cys423, Gly424, Lys426 & - \\
\hline Oseltamivir & $\mathrm{C}_{16} \mathrm{H}_{28} \mathrm{~N}_{2} \mathrm{O}$ & -5.4 & Thr328, Ser412 & $\begin{array}{l}\text { Pro324, Thr328, Pro361, Phe362, } \\
\text { Glu414 }\end{array}$ \\
\hline Chloroquine & $\mathrm{C}_{18} \mathrm{H}_{26} \mathrm{ClN}_{3}$ & -5.3 & THR328 & $\begin{array}{c}\text { Tyr294, Thr328, Pro361, Phe326, } \\
\text { Glu414 }\end{array}$ \\
\hline Favipiravir & $\mathrm{C}_{5} \mathrm{H}_{4} \mathrm{FN}_{3} \mathrm{O}_{2}$ & -5 & $\begin{array}{l}\text { Val239, Ala246, Asn252, } \\
\text { Ser297 }\end{array}$ & \\
\hline \multicolumn{5}{|c|}{ Flavonoids } \\
\hline Ononin & $\mathrm{C}_{22} \mathrm{H}_{22} \mathrm{O}_{9}$ & -7.8 & Thr283, Asp287, Lys427 & Ile230, Pro425 \\
\hline Genistein & $\mathrm{C}_{15} \mathrm{H}_{10} \mathrm{O}_{5}$ & -7.3 & Asn338 & Phe272, Leu339 \\
\hline Luteolin & $\mathrm{C}_{15} \mathrm{H}_{10} \mathrm{O}_{6}$ & -7.2 & $\begin{array}{c}\text { Ser273, Thr274, Tyr278, } \\
\text { Tyr406 }\end{array}$ & Lys276, Val305, Arg306 \\
\hline Morin & $\mathrm{C}_{15} \mathrm{H}_{10} \mathrm{O}_{7}$ & -7.2 & Asn241, Asn338 & Phe240 \\
\hline Fisetin & $\mathrm{C}_{15} \mathrm{H}_{10} \mathrm{O}_{6}$ & -7.1 & $\begin{array}{l}\text { Asp326, Thr328, Pro361, } \\
\text { Phe413 }\end{array}$ & Pro324, Pro361 \\
\hline Taxifolin & $\mathrm{C}_{15} \mathrm{H}_{12} \mathrm{O}_{7}$ & -7.1 & Ala242, Trp334, Arg407 & $\begin{array}{c}\text { Phe240, Asn241, Phe272, Trp334, } \\
\text { Leu339 }\end{array}$ \\
\hline Galangin & $\mathrm{C}_{15} \mathrm{H}_{10} \mathrm{O}_{5}$ & -7 & Asn241, Asn338 & Phe240 \\
\hline Isorhamnetin & $\mathrm{C}_{16} \mathrm{H}_{12} \mathrm{O}_{7}$ & -6.9 & Ser269, Asn338 & Phe240, Phe272 \\
\hline Naringenin & $\mathrm{C}_{15} \mathrm{H}_{12} \mathrm{O}_{5}$ & -6.8 & Ala242, Trp334, Arg407 & $\begin{array}{c}\text { Phe240, Asn241, Phe272, Trp334, } \\
\text { Leu339 }\end{array}$ \\
\hline Quercetin & $\mathrm{C}_{15} \mathrm{H}_{10} \mathrm{O}_{7}$ & -6.6 & Asp326, Thr328, Phe413 & Pro361, Phe362 \\
\hline \multicolumn{5}{|c|}{ Fluorophenyl } \\
\hline $\begin{array}{l}\text { 1,2-Ethanediol, 1,2- } \\
\text { bis(4-fluorophenyl) }\end{array}$ & $\mathrm{C}_{14} \mathrm{H}_{12} \mathrm{~F}_{2} \mathrm{O}_{2}$ & -6.7 & Gly394 & $\begin{array}{c}\text { Asn319, Tyr393 } \\
\text { Tyr403 } \\
\end{array}$ \\
\hline 1,1-bis $(3-$ & C15H14F2O2 & -6.6 & Gly394, Gln396 & Tyr393, Tyr403 \\
\hline
\end{tabular}

Page 16/27 
fluorophenyl)-2-

methoxyethanol

Asn399, Gly400

Phenylpropanoid

\begin{tabular}{|c|c|c|c|c|}
\hline Telmisartan & $\mathrm{C}_{33} \mathrm{H}_{30} \mathrm{~N}_{4} \mathrm{O}_{2}$ & -8.8 & Asp262 & $\begin{array}{l}\text { Val260, Ala261, Gly424,Pro425, } \\
\text { Lys426,Lys } 427\end{array}$ \\
\hline Sennoside & $\mathrm{C}_{42} \mathrm{H}_{38} \mathrm{O}_{20}$ & -8.6 & $\begin{array}{l}\text { Arg253, Asp326, Thr328, } \\
\text { Ser412, Arg364 }\end{array}$ & $\begin{array}{c}\text { Phe327, Lys360, } \\
\text { Pro361,Phe362,Phe413, Glu414 }\end{array}$ \\
\hline Glycyrrhizic acid & $\mathrm{C}_{42} \mathrm{H}_{62} \mathrm{O}_{16}$ & -8.3 & $\begin{array}{l}\text { Pro228, Cys259, Cys423, } \\
\text { Thr421, Lys } 426\end{array}$ & $\begin{array}{l}\text { Phe227, Asn229, Ile230,Arg287, } \\
\text { Leu288, Cys289, Ala420, Val422 }\end{array}$ \\
\hline Verbascoside & $\mathrm{C}_{29} \mathrm{H}_{36} \mathrm{O}_{15}$ & -8.1 & $\begin{array}{l}\text { Val239, Ser247, Asn252, } \\
\text { Ala250, Ser297, Asn348 }\end{array}$ & $\begin{array}{c}\text { Arg244, Phe245, Ala246, Trp251, } \\
\text { Tyr349, Leu350 }\end{array}$ \\
\hline Orobanchoside & $\mathrm{C}_{29} \mathrm{H}_{36} \mathrm{O}_{16}$ & -8 & $\begin{array}{c}\text { Cys259, Ala 420, Thr421, } \\
\text { Cys423, }\end{array}$ & $\begin{array}{c}\text { Trp334, Asn335, Ser336, Asn337, } \\
\text { Asn338, Ala270, Ser271, Phe274, } \\
\text { Ser273 }\end{array}$ \\
\hline Arenarioside & $\mathrm{C}_{34} \mathrm{H}_{44} \mathrm{O}_{19}$ & -7.9 & $\begin{array}{l}\text { Pro228, Asn229, Thr421, } \\
\text { Lys426, Asn442, Cyx259, } \\
\text { Gln462 }\end{array}$ & $\begin{array}{c}\text { Phe227, Ile230, Asn258, Cys 259, } \\
\text { Val260, Val422, Cys423, G424, Pro425 }\end{array}$ \\
\hline Isomartynoside & $\mathrm{C}_{31} \mathrm{H}_{40} \mathrm{O}_{15}$ & -7.8 & Ser264, Pro425 & $\begin{array}{c}\text { Gly424, Lys426, Lys427, Ser428, } \\
\text { Val260, Ala261, Asp262 }\end{array}$ \\
\hline Poliumoside & $\mathrm{C}_{35} \mathrm{H}_{46} \mathrm{O}_{19}$ & -7.8 & Thr421, Pro228, Cys259 & $\begin{array}{l}\text { Phe227, Asn229, Ile230, Asn258, } \\
\text { Val260, Asp287, Leu288, Cys289, } \\
\text { Val422, Cys423, Gly424 }\end{array}$ \\
\hline Teucrioside & $\mathrm{C}_{34} \mathrm{H}_{44} \mathrm{O}_{19}$ & -7.7 & $\begin{array}{c}\text { Asp262, Ser264, Pro425, } \\
\text { Ser428, Gln478 }\end{array}$ & $\begin{array}{l}\text { Phe227, Pro228, Asn229, Ile230, } \\
\text { Gly424, Lys426, Lys427 }\end{array}$ \\
\hline Angoroside A & $\mathrm{C}_{34} \mathrm{H}_{44} \mathrm{O}_{19}$ & -7.7 & Cyx259, Gln462, Pro477 & Asn258, Val260 \\
\hline Pheliposide & $\mathrm{C}_{36} \mathrm{H}_{46} \mathrm{O}_{20}$ & -7.6 & $\begin{array}{l}\text { Asn232, Leu233, Gly237, } \\
\text { Asn241, Thr243, Asp262 }\end{array}$ & $\begin{array}{c}\text { Cys234, Pro235, Phe236, Ala 242, } \\
\text { Val260, Ala261 }\end{array}$ \\
\hline Rutin & $\mathrm{C}_{27} \mathrm{H}_{30} \mathrm{O}_{16}$ & -7.5 & $\begin{array}{c}\text { Arg253, Asp326, Thr328, } \\
\text { Pro361, Arg364, Phe413, } \\
\text { Gln414 }\end{array}$ & Phe327, Gly329, Ser412 \\
\hline Forsythoside B & $\mathrm{C}_{34} \mathrm{H}_{44} \mathrm{O}_{19}$ & -7.5 & $\begin{array}{c}\text { Pro228, Cys 259, Lue288, } \\
\text { Ala420, Cys423, Gly424, } \\
\text { Lys426 }\end{array}$ & Pro 228 \\
\hline Rossicaside A & $\mathrm{C}_{35} \mathrm{H}_{46} \mathrm{O}_{20}$ & -7.4 & $\begin{array}{l}\text { Gln238, Val239, Ser247, } \\
\text { Thr249, Trp251, Asn252, } \\
\text { Arg253, Ser297 }\end{array}$ & $\begin{array}{c}\text { Lys249, Ala250, Tyr347, Asn348, } \\
\text { Tyr349, Leu350 }\end{array}$ \\
\hline Forsythiaside A & $\mathrm{C}_{29} \mathrm{H}_{36} \mathrm{O}_{15}$ & -7.4 & $\begin{array}{c}\text { Phe240, Asn241, Ala270, } \\
\text { Ser271, Phe272, Asn335, } \\
\text { Asn338, Tyr406 }\end{array}$ & $\begin{array}{c}\text { Ser273, Trp334, Ser336, Asn337, } \\
\text { Val401 }\end{array}$ \\
\hline Purpureaside C & $\mathrm{C}_{35} \mathrm{H}_{46} \mathrm{O}_{20}$ & -7.4 & $\begin{array}{l}\text { Leu288, Ala420, Thr421, } \\
\text { Gln462 }\end{array}$ & Phe227 \\
\hline Hesperidin & $\mathrm{C}_{28} \mathrm{H}_{34} \mathrm{O}_{15}$ & -7.4 & $\begin{array}{c}\text { Pro228, Cys 259, Thr421, } \\
\text { Lys } 426\end{array}$ & Phe227, Val260 \\
\hline Isoverbascoside & $\mathrm{C}_{29} \mathrm{H}_{36} \mathrm{O}_{1}$ & -7.4 & $\begin{array}{l}\text { Ala244, Ser247, Trp251, } \\
\text { Asn252, Ser297, Asn348 }\end{array}$ & Ala246, Phe245, Tyr249, Ala250 \\
\hline Leucosceptoside A & $\mathrm{C}_{30} \mathrm{H}_{38} \mathrm{O}_{15}$ & -7.4 & $\begin{array}{l}\text { Asp326, Thr328, Pro361, } \\
\text { Glu414, Leu415 }\end{array}$ & Tyr294, Pro 324, Phe362, Leu415 \\
\hline corosolic acid & $\mathrm{C}_{30} \mathrm{H}_{48} \mathrm{O}_{4}$ & -7.3 & Ser273, Thr406 & $\begin{array}{c}\text { Val305, Arg306, Ala309, Val401, } \\
\text { Tyr406 }\end{array}$ \\
\hline Calceolarioside C & $\mathrm{C}_{28} \mathrm{H}_{34} \mathrm{O}_{15}$ & -7.2 & $\begin{array}{l}\text { Asn241, Ser271, Ser296, } \\
\text { Trp334, Asn335, Asn338 }\end{array}$ & Asn241 \\
\hline
\end{tabular}

Page 17/27 


\begin{tabular}{|c|c|c|c|c|}
\hline Eukovoside & $\mathrm{C}_{30} \mathrm{H}_{38} \mathrm{O}_{15}$ & -7.2 & $\begin{array}{l}\text { Val239, Phe245, Ser247, } \\
\text { Asn348, Ser297 }\end{array}$ & Tyr249, Ile366, Thr368 \\
\hline Angoroside C & $\mathrm{C}_{36} \mathrm{H}_{48} \mathrm{O}_{19}$ & -7.1 & $\begin{array}{l}\text { Asn229, Pro228, Thr231, } \\
\text { Cys259, Thr421, Cys423, } \\
\text { Lys426 }\end{array}$ & Phe227, Pro228, Val260 \\
\hline Conandroside & $\mathrm{C}_{28} \mathrm{H}_{34} \mathrm{O}_{15}$ & -7.1 & $\begin{array}{l}\text { Gln238, Ala250, Trp251, } \\
\text { Asn252, Ser247, Ser297, } \\
\text { Asn348 }\end{array}$ & Ala250, Ile366 \\
\hline Losartan & $\mathrm{C}_{22} \mathrm{H}_{23} \mathrm{ClN}_{6} \mathrm{O}$ & -7.1 & Ser273, Arg306 & $\begin{array}{c}\text { Thr274, Lys276, Val305, Arg306, } \\
\text { Val331, Val401 }\end{array}$ \\
\hline Martynoside & $\mathrm{C}_{31} \mathrm{H}_{40} \mathrm{O}_{15}$ & -7.1 & $\begin{array}{l}\text { Ala246, Ser247, Asn252, } \\
\text { Ser297, Asn348 }\end{array}$ & Tyr249, Ile366 \\
\hline Suspensaside & $\mathrm{C}_{29} \mathrm{H}_{36} \mathrm{O}_{16}$ & -7.1 & $\begin{array}{l}\text { Arg253, Thr328, Lys360, } \\
\text { Arg364, Phe413, Glu414 }\end{array}$ & Tyr294, Phe362 \\
\hline Cistanoside D & $\mathrm{C}_{31} \mathrm{H}_{40} \mathrm{O}_{15}$ & -7 & $\begin{array}{l}\text { Thr328, Phe413, Gly414, } \\
\text { Leu415 }\end{array}$ & $\begin{array}{l}\text { Tyr294, Pro324, Pro361, } \\
\text { Phe362,Leu415 }\end{array}$ \\
\hline Osmanthuside B & $\mathrm{C}_{29} \mathrm{H}_{36} \mathrm{O}_{13}$ & -7 & $\begin{array}{c}\text { Cys259, Ala420, Thr421, } \\
\text { Cys423 } \\
\end{array}$ & $\begin{array}{l}\text { Phe227, Pro228, Thr231, Val260, } \\
\text { Lys426, Pro 477 }\end{array}$ \\
\hline Tubuloside A & $\mathrm{C}_{37} \mathrm{H}_{48} \mathrm{O}_{21}$ & -6.9 & $\begin{array}{c}\text { Arg253, Thr328, Asp326, } \\
\text { Phe362, Arg364 }\end{array}$ & Pro324, Phe362, Glu363, Glu414 \\
\hline Grayanoside B & $\mathrm{C}_{26} \mathrm{H}_{42} \mathrm{O}_{9}$ & -6.9 & Cys259, Thr421, Asn442 & Phe227, Thr231, Lys426 \\
\hline Campneoside & $\mathrm{C}_{30} \mathrm{H}_{38} \mathrm{O}_{16}$ & -6.7 & $\begin{array}{c}\text { Pro228, Asn229, Cys259, } \\
\text { Val260, Cys423 } \\
\text { Gly424 }\end{array}$ & Val260 \\
\hline Cistanoside C & $\mathrm{C}_{30} \mathrm{H}_{38} \mathrm{O}_{15}$ & -6.7 & $\begin{array}{c}\text { Pro228, Asn229, Cys259, } \\
\text { Cys423 }\end{array}$ & Phe227, Val260 \\
\hline Grayanoside A & $\mathrm{C}_{24} \mathrm{H}_{28} \mathrm{O}_{10}$ & -6.7 & T328, Pro361, Phe413 & Tyr294, Pro324, Phe362 \\
\hline Oleuropein & $\mathrm{C}_{25} \mathrm{H}_{32} \mathrm{O}_{13}$ & -6.5 & $\begin{array}{l}\text { Thr231, Asn258, Leu288, } \\
\text { Ala420, Gly424 }\end{array}$ & THE231 \\
\hline Stachyoside & $\mathrm{C}_{25} \mathrm{H}_{28} \mathrm{~N}_{2} \mathrm{O}_{8}$ & -6.3 & Arg253, Asp261, Pro361 & Tyr294, Phe362 \\
\hline Tubuloside C & $\mathrm{C}_{37} \mathrm{H}_{48} \mathrm{O}_{21}$ & -6.3 & Arg253, Thr325, Arg364 & $\begin{array}{c}\text { Pro324, Pro361, Phe362, Glu414, } \\
\text { Leu416 }\end{array}$ \\
\hline Salidroside & $\mathrm{C}_{14} \mathrm{H}_{20} \mathrm{O}_{7}$ & -6.1 & $\begin{array}{c}\text { Ala242, Ser269, Thr334, } \\
\text { Arg407 }\end{array}$ & Phe240, Trp334 \\
\hline \multicolumn{5}{|c|}{ Propane } \\
\hline $\begin{array}{l}\text { 1,2-Propanediol, 3,3,3- } \\
\text { trifluoro-2-phenyl-, } \\
\text { (2R) }\end{array}$ & C9H9F3O2 & -6.7 & Gly394 & $\begin{array}{l}\text { Tyr393, Asn399 } \\
\text { Tyr403 }\end{array}$ \\
\hline $\begin{array}{l}\text { 1,1-diphenyl propane- } \\
\text { 1,2-diol }\end{array}$ & $\mathrm{C}_{14} \mathrm{H}_{14} \mathrm{O}_{2}$ & -6.4 & Gly394, Asn399 & $\begin{array}{l}\text { Arg301, Tyr393 } \\
\text { TYR403 }\end{array}$ \\
\hline $\begin{array}{c}\text { (S)-1,1- } \\
\text { Diphenylpropane-1,2- } \\
\text { diol }\end{array}$ & C15H16O2 & -6.2 & $\begin{array}{l}\text { Gly394, Gln396 } \\
\text { Asn399 }\end{array}$ & Tyr393, Tyr403 \\
\hline
\end{tabular}

Table 2 Summary of top seven ranked ligands screened against RBD of Spike 2019 n-cov2, with their respective classification, Chemical formula, binding affinity, hydrogen, and hydrophobic interacting residues. 


\begin{tabular}{|c|c|c|c|c|c|c|c|}
\hline \multirow[t]{2}{*}{ Ligand name } & \multirow{2}{*}{$\begin{array}{l}\text { Pubchem } \\
\text { ID }\end{array}$} & \multicolumn{3}{|c|}{ Open state } & \multicolumn{3}{|c|}{ Closed state } \\
\hline & & $\begin{array}{c}\text { Binding } \\
\text { Affinity } \\
\text { (Kcal/mol) }\end{array}$ & $\begin{array}{l}\text { Hydrogen } \\
\text { bond }\end{array}$ & Hydrophobic bond & $\begin{array}{c}\text { Binding } \\
\text { Affinity } \\
\text { (Kcal/mol) }\end{array}$ & $\begin{array}{l}\text { Hydrogen } \\
\text { bond }\end{array}$ & $\begin{array}{l}\text { Hydrophobic } \\
\text { bond }\end{array}$ \\
\hline Rossicaside A & 13916145 & -7.5 & $\begin{array}{c}\text { Gln238 } \\
\text { Val239 } \\
\text { Ser247 } \\
\text { Thr249 } \\
\text { Trp251 } \\
\text { Asn252 } \\
\text { Arg253 } \\
\text { Ser297 }\end{array}$ & $\begin{array}{l}\text { Lys249 Ala250 } \\
\text { Tyr347Asn348 } \\
\text { Tyr349 Leu350 }\end{array}$ & -6.8 & $\begin{array}{l}\text { Ala257 } \\
\text { Ser284 } \\
\text { Ser286 } \\
\text { Asn353 } \\
\text { Asn350 }\end{array}$ & $\begin{array}{l}\text { Phe255 } \\
\text { Leu354 }\end{array}$ \\
\hline Etravirine & 193962 & -7.4 & Ser271 & $\begin{array}{l}\text { Phe240 } \\
\text { Asn241 } \\
\text { Trp334 } \\
\text { Leu339 }\end{array}$ & -6.7 & Gly409 & $\begin{array}{l}\text { Phe377 } \\
\text { Glu429 }\end{array}$ \\
\hline $\begin{array}{l}\text { 1,2-Ethanediol, 1,2- } \\
\text { bis (4-fluorophenyl) }\end{array}$ & 2755890 & -6.7 & Gly394 & $\begin{array}{l}\text { Asn319 } \\
\text { Tyr393 } \\
\text { Tyr403 }\end{array}$ & -6.7 & - & $\begin{array}{r}\text { Tyr408 } \\
\text { Asn414 } \\
\text { Tyr418 }\end{array}$ \\
\hline $\begin{array}{c}\text { 1,2-Propanediol, } \\
\text { 3,3,3-trifluoro-2- } \\
\text { phenyl-(2R) }\end{array}$ & 11095754 & -6.7 & Gly394 & $\begin{array}{c}\text { Tyr393 } \\
\text { Asn399 } \\
\text { Tyr403 }\end{array}$ & -6.7 & Asn414 & $\begin{array}{l}\text { Tyr408 } \\
\text { Asn414 }\end{array}$ \\
\hline $\begin{array}{l}\text { 1,1-bis(3- } \\
\text { fluorophenyl)-2- } \\
\text { methoxyethanol }\end{array}$ & 53722331 & -6.6 & $\begin{array}{r}\text { Gly394 } \\
\text { Gln396 } \\
\text { Asn399 } \\
\text { Gly400 } \\
\end{array}$ & Tyr393 Tyr403 & -6.6 & $\begin{array}{r}\text { Gly409 } \\
\text { Gln411 } \\
\text { Asn414 } \\
\text { Gly415 } \\
\end{array}$ & $\begin{array}{c}\text { Tyr408 } \\
\text { Asn414Tyr418 }\end{array}$ \\
\hline $\begin{array}{l}\text { 1,1-diphenyl } \\
\text { propane-1,2-diol }\end{array}$ & 555451 & -6.4 & $\begin{array}{l}\text { Gly394 } \\
\text { Asn399 }\end{array}$ & $\begin{array}{l}\text { Arg301 } \\
\text { Tyr393 } \\
\text { TYR403 }\end{array}$ & -6.4 & $\begin{array}{r}\text { Gln411 } \\
\text { Asn414 }\end{array}$ & $\begin{array}{l}\text { Arg316 } \\
\text { Tyr408 } \\
\text { Tyr418 } \\
\end{array}$ \\
\hline $\begin{array}{c}\text { (S)-1,1- } \\
\text { Diphenylpropane- } \\
\text { 1,2-diol }\end{array}$ & 736300 & -6.2 & $\begin{array}{l}\text { Gly394 } \\
\text { Gln396 } \\
\text { Asn399 }\end{array}$ & $\begin{array}{l}\text { Tyr393 } \\
\text { Tyr403 }\end{array}$ & -6.4 & $\begin{array}{l}\text { Gly409 } \\
\text { Asn414 }\end{array}$ & $\begin{array}{l}\text { Arg316 } \\
\text { Tyr408 } \\
\text { Tyr418 } \\
\end{array}$ \\
\hline
\end{tabular}

Table 3 ADME Properties of selected ligands against $\mathrm{S}^{\mathrm{B}}$ domain. 


\begin{tabular}{|c|c|c|c|c|}
\hline No & Ligands & \multicolumn{2}{|l|}{ ADME Properties } & $\begin{array}{l}\text { Drug } \\
\text { Likeliness }\end{array}$ \\
\hline \multirow[t]{6}{*}{1} & \multirow[t]{6}{*}{ 1,1-diphenyl propane-1,2-diol } & Molecular weight (<500 Da) & $228.29 \mathrm{~g} / \mathrm{mol}$ & \multirow[t]{6}{*}{ Yes } \\
\hline & & $\log P(<5)$ & 2.85 & \\
\hline & & H-bond donar (5) & 2 & \\
\hline & & H-bond acceptor $(<10)$ & 2 & \\
\hline & & Molar Refractivity (40-130) & 67.72 & \\
\hline & & Violations & NO & \\
\hline \multirow[t]{6}{*}{2} & \multirow[t]{6}{*}{ 1,2-Propanediol, 3,3,3-trifluoro-2-phenyl-(2R) } & Molecular weight (<500 Da) & $206.16 \mathrm{~g} / \mathrm{mol}$ & \multirow[t]{6}{*}{ Yes } \\
\hline & & $\log \mathrm{P}(<5)$ & 1.59 & \\
\hline & & H-bond donar (5) & 5 & \\
\hline & & H-bond acceptor $(<10)$ & 2 & \\
\hline & & Molar Refractivity (40-130) & 43.42 & \\
\hline & & Violations & $\mathrm{NO}$ & \\
\hline \multirow[t]{6}{*}{3} & \multirow[t]{6}{*}{ 1,1-bis(3-fluorophenyl)-2-methoxyethanol } & Molecular weight (<500 Da) & $264.27 \mathrm{~g} / \mathrm{mol}$ & \multirow[t]{6}{*}{ Yes } \\
\hline & & $\log P(<5)$ & 2.84 & \\
\hline & & H-bond donar (5) & 1 & \\
\hline & & H-bond acceptor $(<10)$ & 4 & \\
\hline & & Molar Refractivity (40-130) & 67.55 & \\
\hline & & Violations & NO & \\
\hline \multirow[t]{6}{*}{4} & \multirow[t]{6}{*}{ 1,2-Ethanediol, 1,2-bis(4-fluorophenyl) } & Molecular weight (<500 Da) & $250.24 \mathrm{~g} / \mathrm{mol}$ & \\
\hline & & $\log P(<5)$ & 1.76 & \\
\hline & & H-bond donar (5) & 2 & \\
\hline & & H-bond acceptor $(<10)$ & 4 & \\
\hline & & Molar Refractivity (40-130) & 62.94 & \\
\hline & & Violations & $\mathrm{NO}$ & \\
\hline \multirow[t]{6}{*}{5} & \multirow[t]{6}{*}{ Etravirine } & Molecular weight (<500 Da) & $435.28 \mathrm{~g} / \mathrm{mol}$ & \multirow[t]{6}{*}{ Yes } \\
\hline & & $\log \mathrm{P}(<5)$ & 3.2 & \\
\hline & & H-bond donar (5) & 2 & \\
\hline & & H-bond acceptor $(<10)$ & 5 & \\
\hline & & Molar Refractivity (40-130) & 109.56 & \\
\hline & & Violations & NO & \\
\hline \multirow[t]{2}{*}{6} & \multirow[t]{2}{*}{ Rossicaside A } & Molecular weight (<500 Da) & $786.73 \mathrm{~g} / \mathrm{mol}$ & \multirow[t]{2}{*}{ No } \\
\hline & & $\log P(<5)$ & 2.79 & \\
\hline
\end{tabular}




\begin{tabular}{|c|c|c|c|c|}
\hline & & H-bond donar (5) & 12 & \\
\hline & & H-bond acceptor $(<10)$ & 20 & \\
\hline & & Molar Refractivity (40-130) & 180.81 & \\
\hline & & Violations & 3 & \\
\hline \multirow[t]{6}{*}{7} & \multirow[t]{6}{*}{ (S)-1,1-Diphenylpropane-1,2-diol } & Molecular weight (<500 Da) & $228.29 \mathrm{~g} / \mathrm{mol}$ & \multirow[t]{6}{*}{ Yes } \\
\hline & & $\log P(<5)$ & 2.15 & \\
\hline & & H-bond donar (5) & 2 & \\
\hline & & H-bond acceptor $(<10)$ & 2 & \\
\hline & & Molar Refractivity (40-130) & 67.72 & \\
\hline & & Violations & $\mathrm{NO}$ & \\
\hline
\end{tabular}

Table 4 FAF-Drugs3 and pan assay interference (PAINS) filtering of 7 identified ligands.

\begin{tabular}{|l|l|l|l|}
\hline $\mathrm{N}$ & Ligand & FAF-Drugs3 filtering & PAINS filtering \\
\hline 1 & 1,1-diphenylpropane-1,2-diol & Accepted & None \\
\hline 2 & 1,2-Propanediol, 3,3,3-trifluoro-2-phenyl-(2R) & Accepted & None \\
\hline 3 & 1,1-bis(3-fluorophenyl)-2-methoxyethanol & Accepted & None \\
\hline 4 & 1,2 -Ethanediol, 1,2-bis(4-fluorophenyl) & Accepted & \\
\hline 5 & Etrinavir & Accepted & None \\
\hline 6 & Rossicaside A & Rejected & None \\
\hline 7 & (S)-1,1-Diphenylpropane-1,2-diol & Accepted & catechol \\
\hline
\end{tabular}

Table 5 AVCpred analysis for seven final ligands. 


\begin{tabular}{|l|l|l|l|l|l|l|}
\hline $\mathrm{N}$ & Ligand & General & HBV & HCV & HHV & HIV \\
\hline 1 & 1,1-diphenylpropane-1,2-diol & 28.41 & 26.79 & 24.95 & 16.43 & 75.45 \\
\hline 2 & 1,2 -Propanediol, 3,3,3-trifluoro-2-phenyl-(2R) & 25.53 & 22.97 & 27.15 & 18.31 & 59.56 \\
\hline 3 & 1,1-bis(3-fluorophenyl)-2-methoxyethanol & 41.68 & 26.57 & 31.10 & 10.74 & 63.49 \\
\hline 4 & 1,2 -Ethanediol, 1,2-bis(4-fluorophenyl) & 29.87 & 26.41 & 39.13 & 7.45 & 61.41 \\
\hline 5 & Etrinavir & & & & & \\
\hline 6 & Rossicaside A & 74.78 & 22.53 & 38.38 & 25.04 & 70.97 \\
\hline 7 & (S)-1,1-Diphenylpropane-1,2-diol & 28.41 & 26.79 & 24.95 & 16.43 & 75.45 \\
\hline
\end{tabular}

\section{Figures}

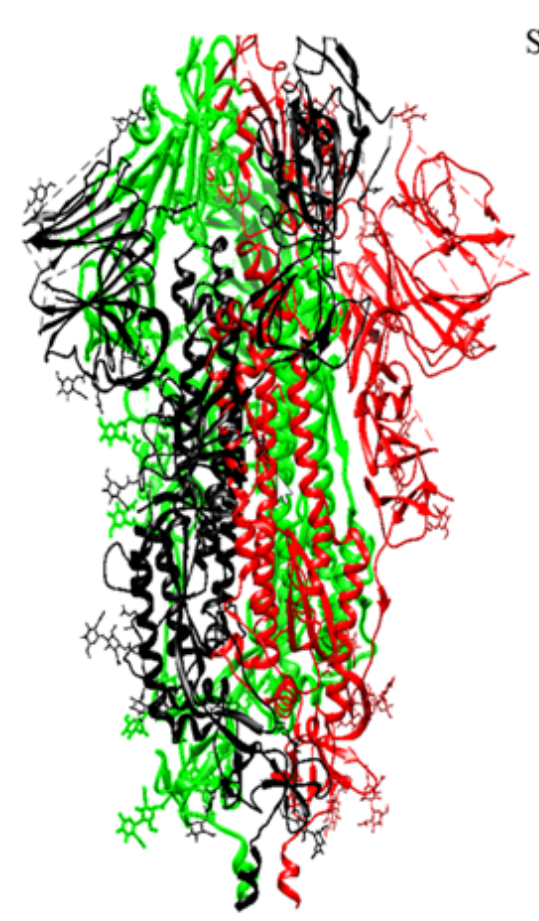

A

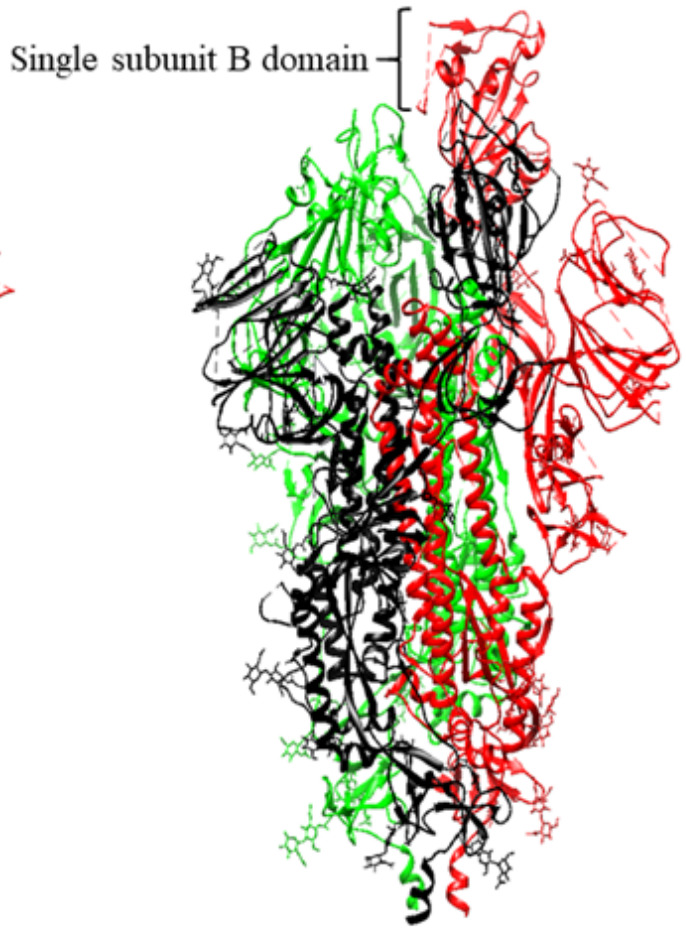

B

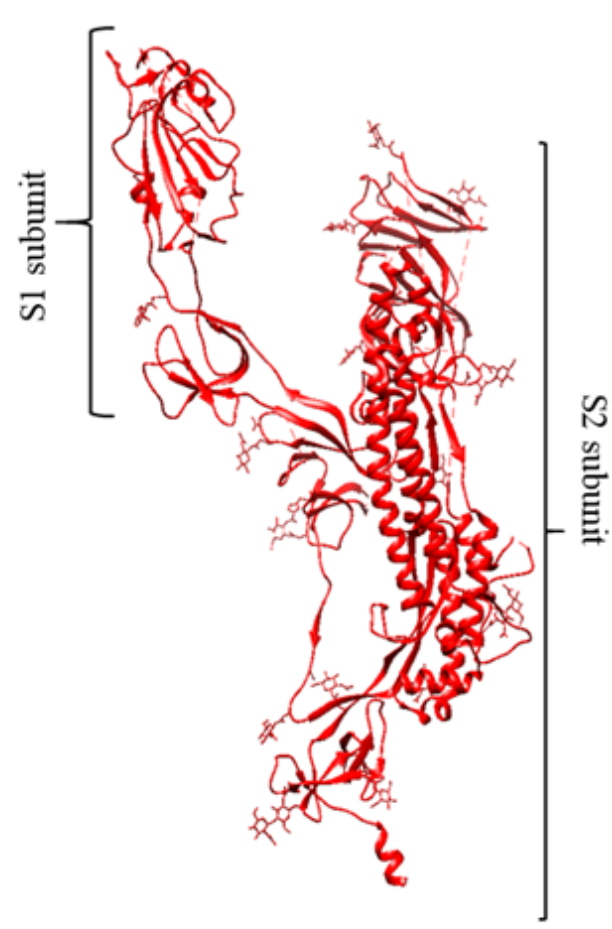

C

Figure 1 
A: Closed SARS-CoV-2 spike glycoprotein trimer. B: Opened SARS-CoV-2 spike glycoprotein trimer. C: The monomer of $S$ glycoprotein with different subunits. Three different colors represent three monomers spike glycoprotein: A, B, C respectively black, red, green.

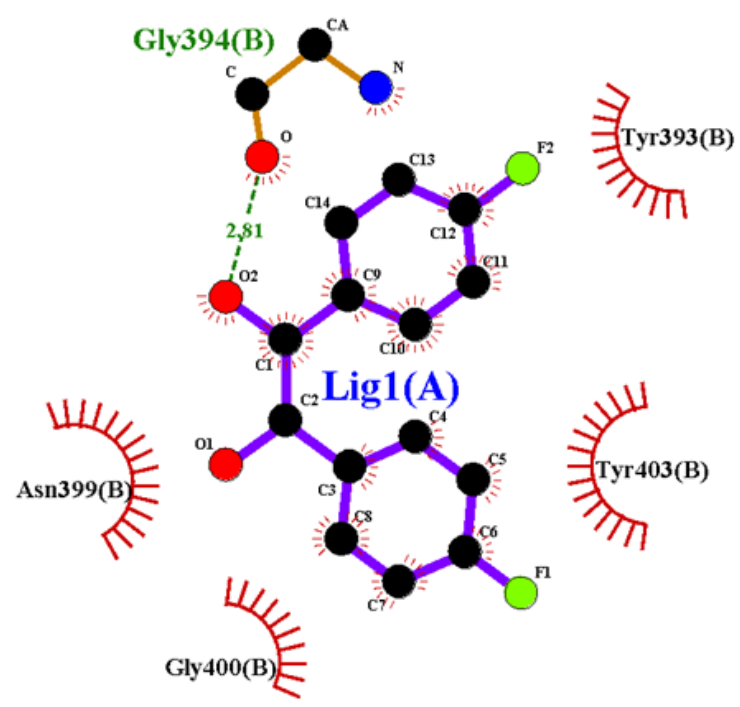

A

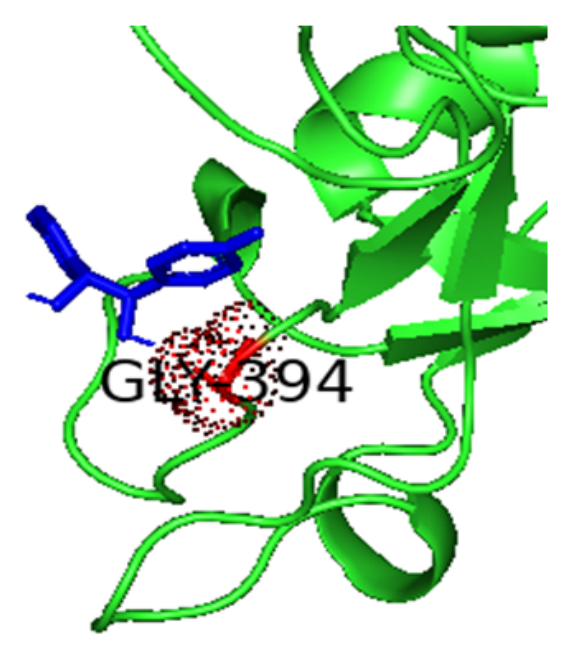

B

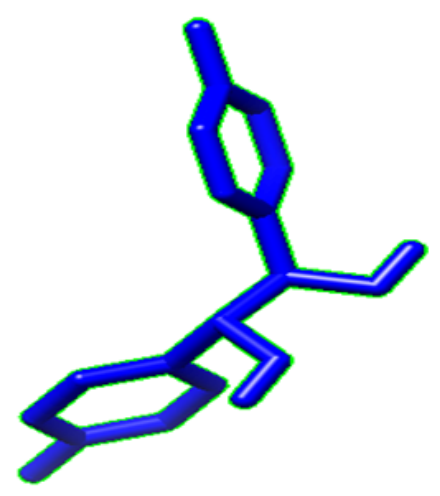

C

Figure 2

A. LigPlot+ analyses result in the Open state of binding conformation of 1,2-Ethanediol, 1,2-bis(4fluorophenyl). B: The interacting binding site amino acid residue of SARS-CoV-2S with 1,2-Ethanediol, 1,2bis (4-fluorophenyl). C: 1,2-Ethanediol, 1,2-bis (4-fluorophenyl) (Ligand).

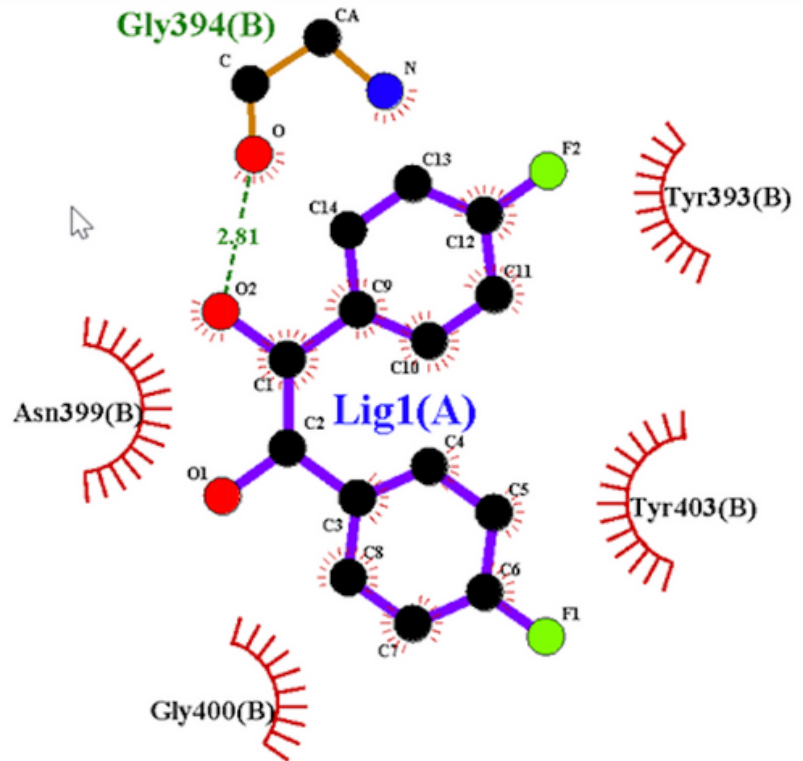

A
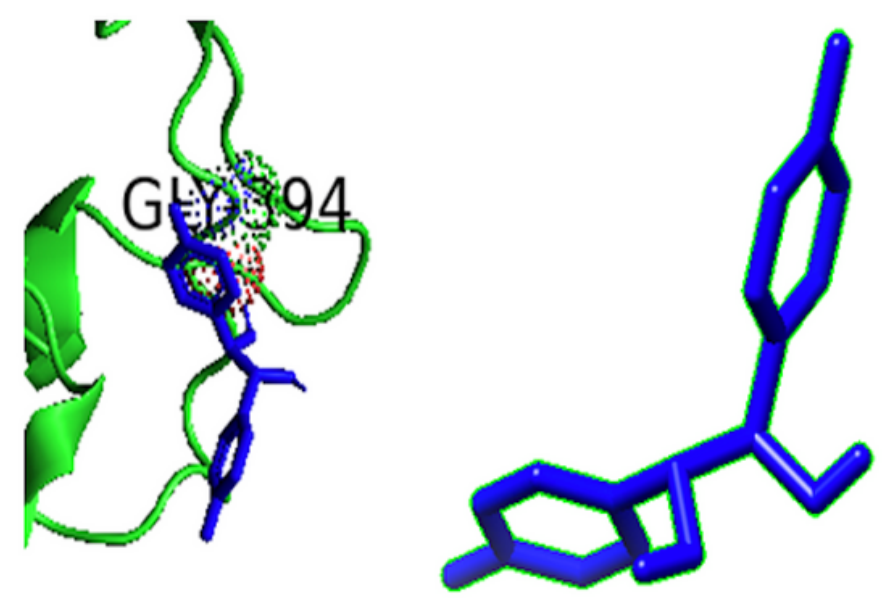

Figure 3 
A: LigPlot+ analyses result in the Open state of binding conformation of 1,2-Propanediol, 3,3,3-trifluoro-2phenyl-, (2R) B: The interacting binding site amino acid residue of SARS-CoV-2S with 1,2-Propanediol, 3,3,3-trifluoro-2-phenyl-, (2R), C: 1,2-Propanediol, 3,3,3-trifluoro-2-phenyl-, (2R) (Ligand).

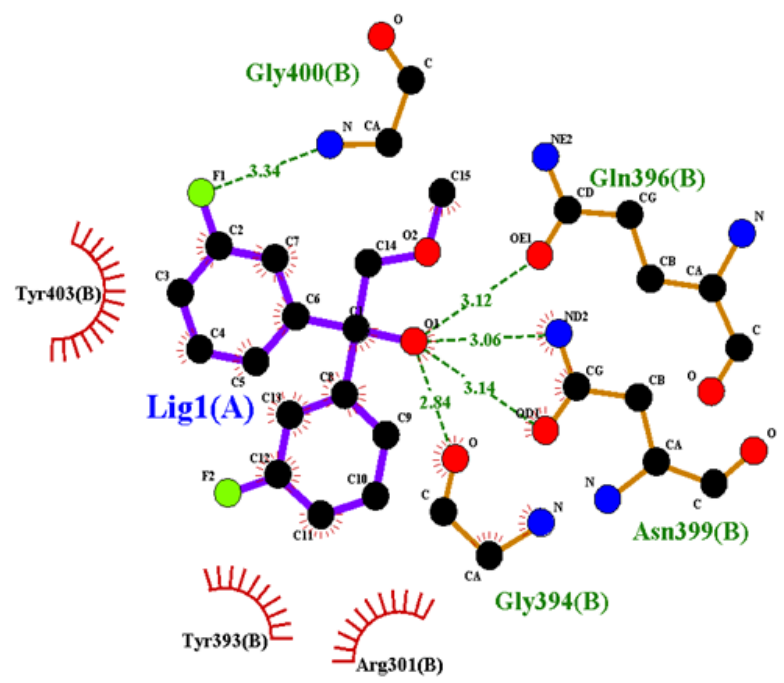

A

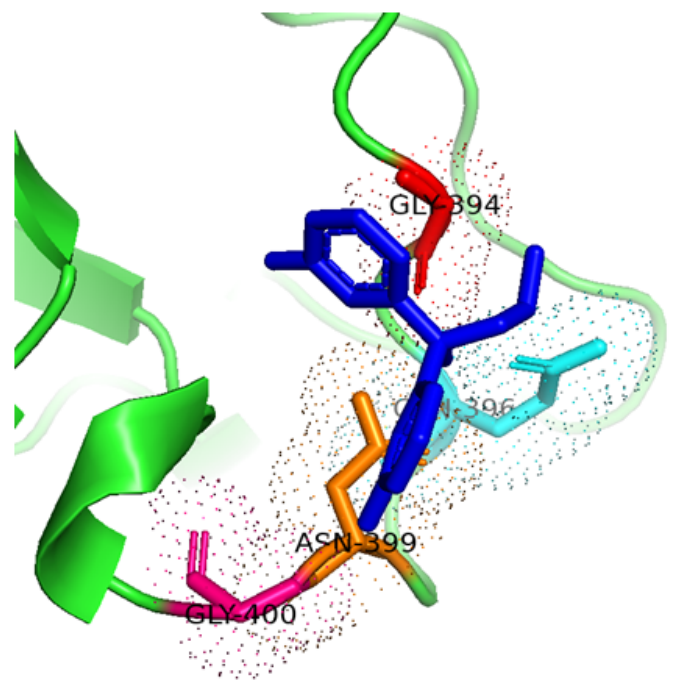

B

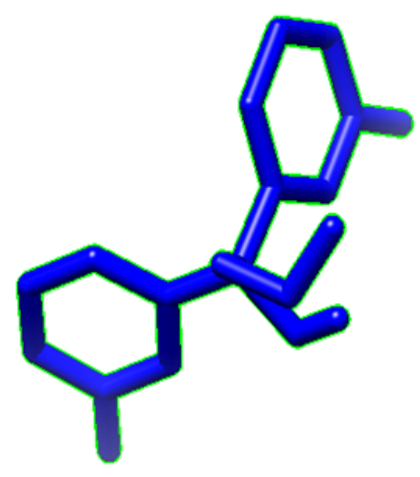

C

\section{Figure 4}

A: LigPlot+ analyses result in the Open state of binding conformation of 1,1-bis(3-fluorophenyl)-2methoxyethanol B: The interacting binding site amino acid residue of SARS-CoV-2S with 1,1-bis(3fluorophenyl)-2-methoxyethanol, C: 1,1-bis(3-fluorophenyl)-2-methoxyethanol (Ligand).

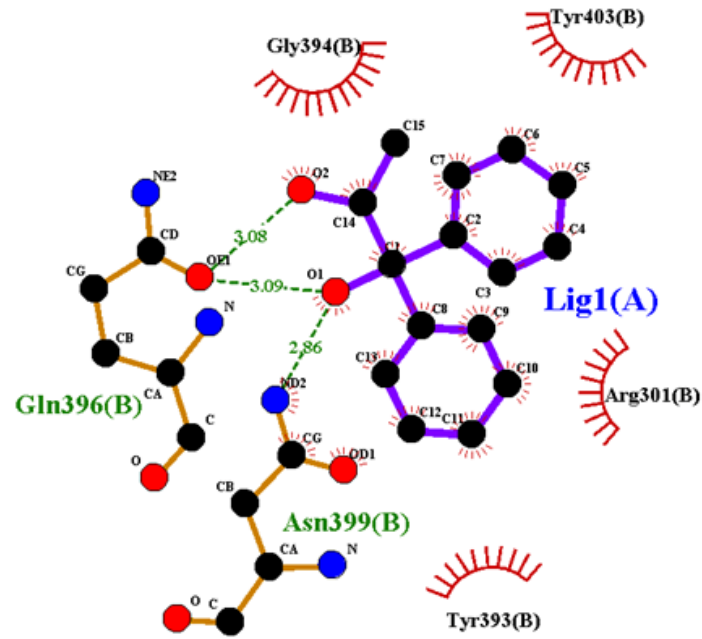

A

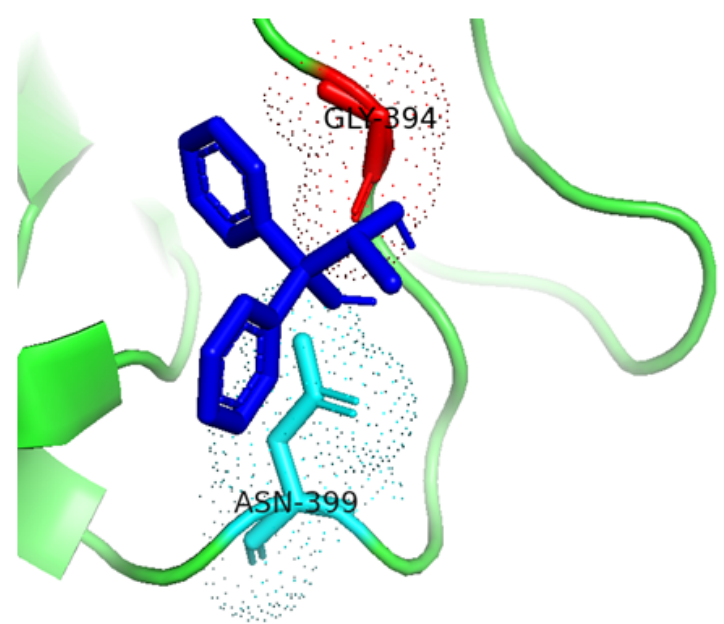

B

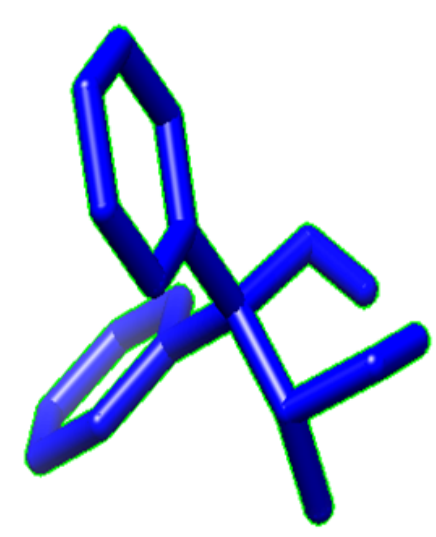

C

Figure 5

A: LigPlot+ analyses result in the Open state of binding conformation of 1,1-diphenyl propane-1,2-diol. B: The interacting binding site amino acid residue of SARS-CoV-2S with 1,1-diphenyl propane-1,2-diol. C: 1,1diphenyl propane-1,2-diol (Ligand). 


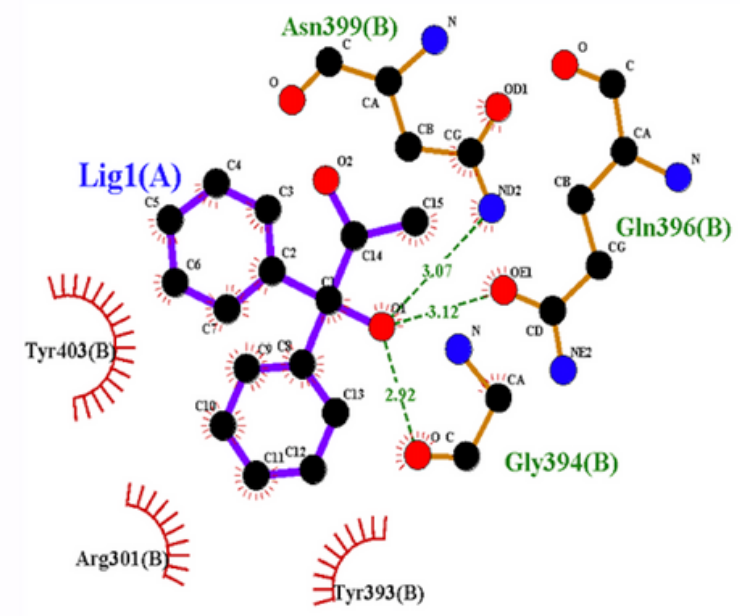

A

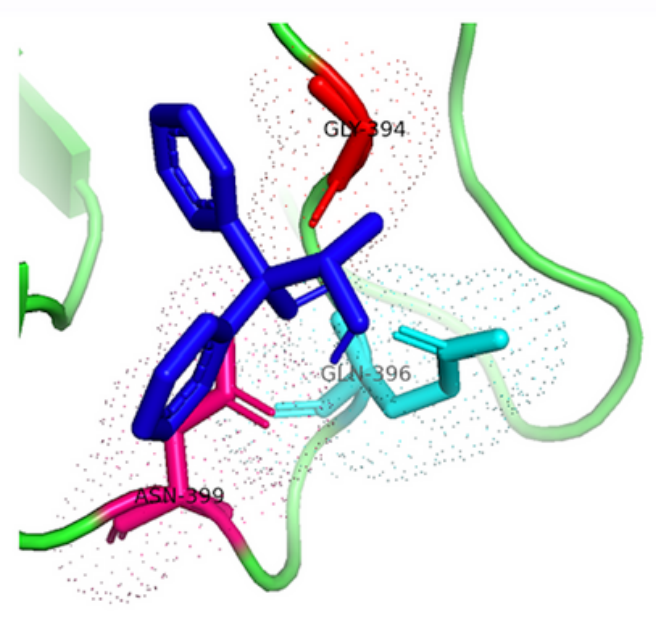

B

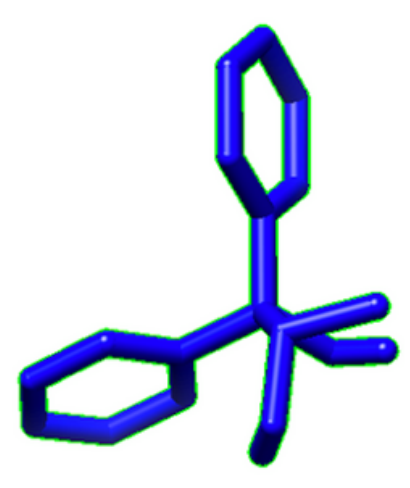

C

\section{Figure 6}

A: LigPlot+ analyses result in the Open state of binding conformation of (S)-1,1-Diphenylpropane-1,2-diol B: The interacting binding site amino acid residue of SARS-CoV-2S with (S)-1,1-Diphenylpropane-1,2-diol, C: (S)-1,1-Diphenylpropane-1,2-diol (Ligand). 

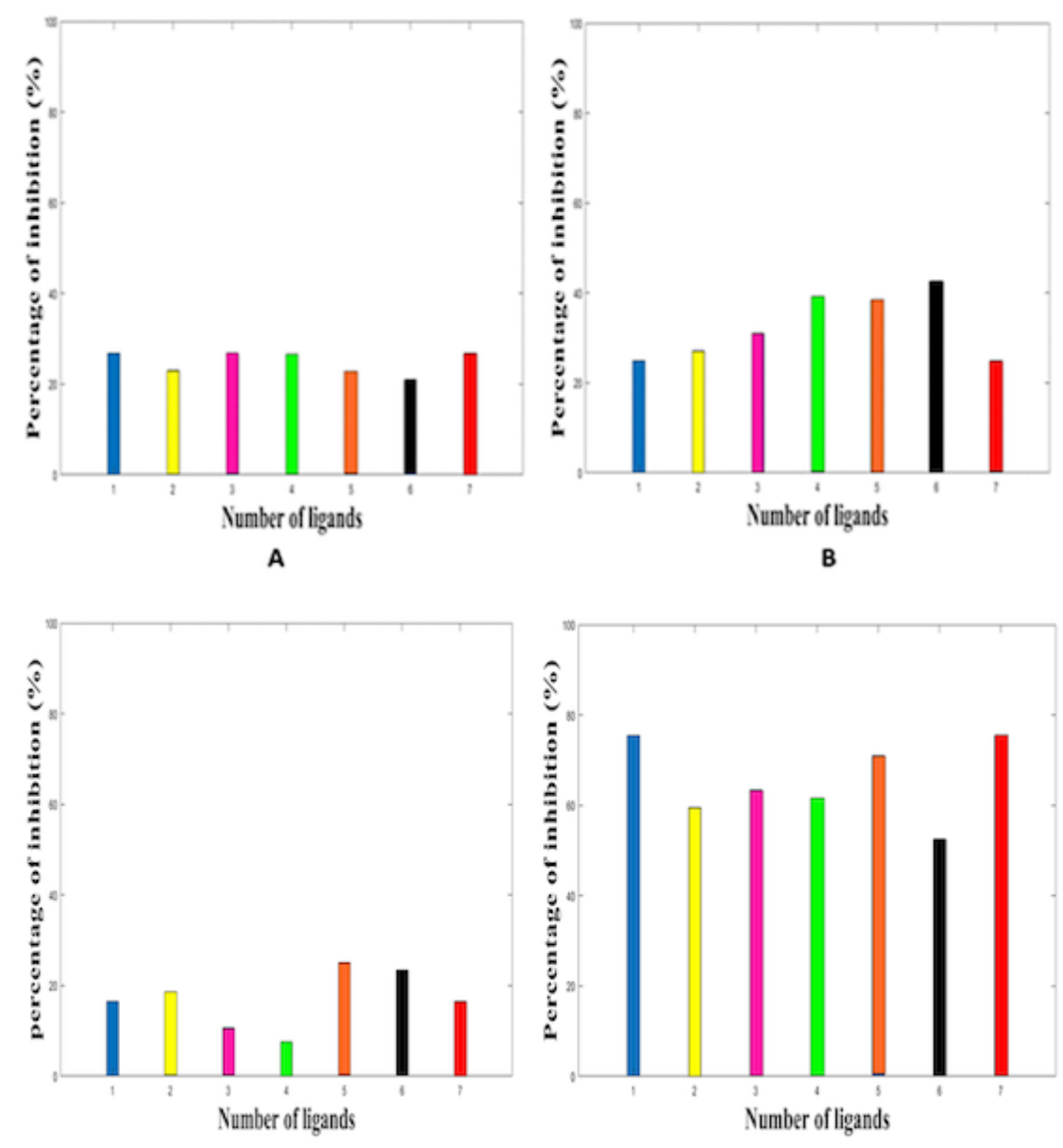

C

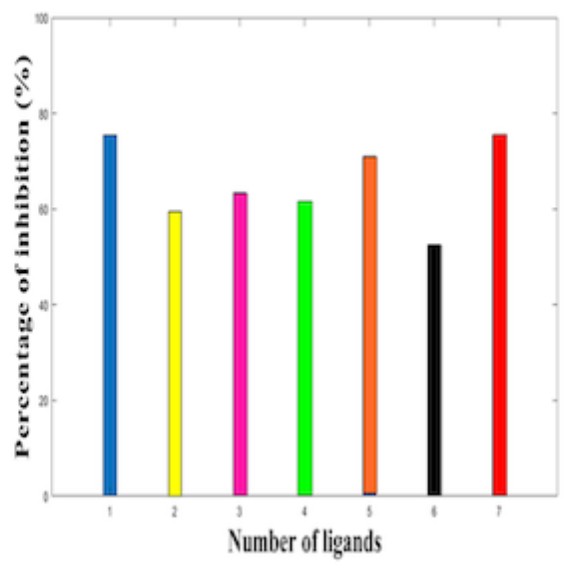

D

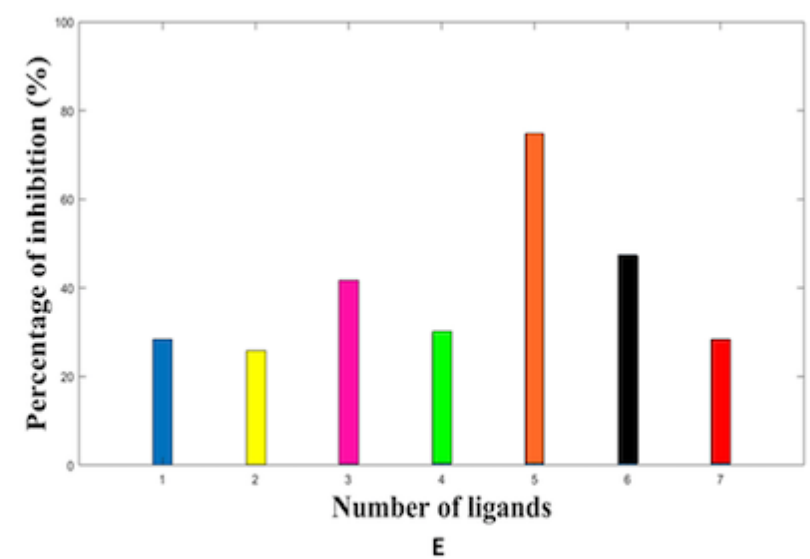

Figure 7

A Bar plot of percentage of inhibition prediction: A) HBV, B) HCV, C) HHV, D) HIV, and E) General (26 viruses). 1-1-diphenylpropane-1-2-diol, 1-2-Propanediol. 3.3.3-trifluoro-2-phenyl-(2R), 1.1-bis(3fluorophenyl)-2-methoxyethanol, 1.2-Ethanediol, 1.2-bis(4-fluorophenyl), Etrinavir, Rossicaside A, and (S)-1,1-Diphenylpropane-1,2-diol are shown respectively: Blue, yellow, pink, green, orange, black, and red. 


\section{Supplementary Files}

This is a list of supplementary files associated with this preprint. Click to download.

- SupportTablesS1.docx

- SupportfiguresS2.docx 